\title{
Id2 Is Required for Specification of Dopaminergic Neurons during Adult Olfactory Neurogenesis
}

\author{
Matthew C. Havrda, ${ }^{1,2}$ Brent T. Harris, ${ }^{4}$ Akio Mantani, ${ }^{5}$ Nora M. Ward, ${ }^{1,2}$ Brenton R. Paolella, ${ }^{1,2}$ Verginia C. Cuzon, ${ }^{3}$ \\ Hermes H. Yeh, ${ }^{3}$ and Mark A. Israel ${ }^{1,2}$ \\ ${ }^{1}$ Norris Cotton Cancer Center and Departments of ${ }^{2}$ Genetics and ${ }^{3}$ Physiology, Dartmouth Medical School, and ${ }^{4}$ Department of Pathology, Dartmouth- \\ Hitchcock Medical Center, Lebanon, New Hampshire 03756, and 5 Division of Psychiatry, Yoshida General Hospital, Hiroshima 731-05, Japan
}

Understanding the biology of adult neural stem cells has important implications for nervous system development and may contribute to our understanding of neurodegenerative disorders and their treatment. We have characterized the process of olfactory neurogenesis in adult mice lacking inhibitor of DNA binding $2^{-l-}\left(I d 2^{-/}\right)$. We found a diminished olfactory bulb containing reduced numbers of granular and periglomerular neurons with a distinct paucity of dopaminergic periglomerular neurons. While no deficiency of the stem cell compartment was detectable, migrating neuroblasts in $I d 2^{-l-}$ mutant mice prematurely undergo astroglial differentiation within a disorganized rostral migratory stream. Further, when evaluated in vitro loss of $I d 2$ results in decreased proliferation of neural progenitors and decreased expression of the Hes1 and Ascl1 (Mash1) transcription factors, known mediators of neuronal differentiation. These data support a novel role for sustained $I d 2$ expression in migrating neural progenitors mediating olfactory dopaminergic neuronal differentiation in adult animals.

Key words: Id2; dopaminergic; olfactory; adult; neurogenesis; subventricular zone

\section{Introduction}

A subset of olfactory bulb (OB) neurons in adult mice undergo apoptotic death and are replaced by ongoing neurogenesis (Petreanu and Alvarez-Buylla, 2002). Stem cells responsible for replacement of olfactory neurons reside in the subventricular zone (SVZ), a cell compartment lining the anterior lateral ventricles (Lois et al., 1996; Doetsch et al., 1997; Garcia-Verdugo et al., 1998; Petreanu and Alvarez-Buylla, 2002). Studies of neuronal progenitors residing in the SVZ indicate three distinguishable cell types. These include PSA-NCAM or Doublecortin (Dcx) expressing migrating neuroblasts (type-A cells), proliferative GFAP expressing cells (type-B cells), and transient amplifying precursor cells (type-C cells) (Porteus et al., 1994; Yun et al., 2001; Stenman et al., 2003; Kohwi et al., 2005).

The adult SVZ is the sole source of adult born olfactory neurons (Lemasson et al., 2005). The granular cell layer (GCL) and periglomerular cell layer (PGL) interneurons replaced in the $\mathrm{OB}$ are diverse in their neurotransmitter profile (Shepherd et al., 2007). Two distinct olfactory interneurons make up the majority

Received July 9, 2008; revised Aug. 19, 2008; accepted Nov. 13, 2008.

This work was supported by the Theodora B. Betz Foundation (M.A.I.) and by National Institutes of HealthNational Institute of Neurological Disorders and Stroke Fellowship 1F32NS059126-01A1 (M.C.H.). We greatly appreciate the expert assistance of Sarah Purdy Gilman in all animal experiments reported in this manuscript. We thank Dr. Lucy Liaw (Maine Medical Center Research Institute) for N1ICD and Hes1-luciferase constructs. We thank the laboratories of Drs. Hermes Yeh and Valerie Galton for assistance with histologic and anosmia techniques, respectively. We thank Drs. Stephen Lee and Harker Rhodes for ongoing discussions and guidance in the analysis of dopaminergic neurons. For editing this manuscript, we thank Tabatha Richardson, for statistical assistance, we thank Dr. Jiang Gui, and for technical assistance, we thank Eric York and Eve Kemble.

Correspondence should be addressed to Dr. Matthew C. Haurda, Norris Cotton Cancer Center, Dartmouth Medical School, 1 Medical Center Drive, Rubin 7, Room 751, Lebanon, NH 03756. E-mail: Matthew.C.Havrda@Dartmouth.edu. DOl:10.1523/JNEUROSCI.3188-08.2008

Copyright $\odot 2008$ Society for Neuroscience $\quad$ 0270-6474/08/2814074-13\$15.00/0 of those arising in adults: GABAergic, calretinin (CR) expressing neurons, and dopaminergic tyrosine hydroxylase (TH) expressing neurons (De Marchis et al., 2007). Small eye mice carry a mutation in the Pax6 gene and the eyes and olfactory system of these animals fail to develop. Studies of mice hemizygous for Pax6 reveal a depletion of OB dopaminergic neurons (Stoykova and Gruss, 1994; Dellovade et al., 1998; Kohwi et al., 2005).

During neurogenesis highly conserved proneural basic helixloop-helix (bHLH) transcription factor dimers mediate differentiation (Guillemot, 1999; Bertrand et al., 2002; Chae et al., 2004). These include Ascl1 (Mash1) and genes of the Neurogenin ( Ngn) and NeuroD families (Guillemot, 1999). High levels of neuroinhibitory Hes 1 are expressed in the SVZ and RMS allowing stem and progenitor cells to proliferate en route to the OB where Hes 1 expression diminishes and neuronal differentiation occurs (Ohtsuka et al., 2006).

Members of the Id gene family inhibit the activity of bHLH transcription factors by blocking their dimerization with bHLH proteins (Benezra et al., 1990; Jögi et al., 2002). Most commonly this results in the inhibition of differentiation (Cai et al., 2000) and promotion of proliferation (Iavarone et al., 1994). Id expression is very limited in adult tissues but is detectable in distinct populations of adult postmitotic neurons including the GCL and PGL of the OB and striatal dopaminergic cells including the caudate-putamen and substantia nigra (SN) (Kitajima et al., 2006). We observed that the brains of inhibitor of DNA binding $2^{-1-}$ $\left(\mathrm{Id} 2^{-/-}\right)$mice appear to develop normally although the $\mathrm{OB}$ of adults is significantly smaller than it is in wild-type (WT) littermates. While Id2 appears dispensable for adult SVZ function, neuronal precursors have an altered differentiation potential resulting in decreased OB dopaminergic neurons. Finally, we dem- 
onstrate that loss of Id2 inhibition of Hes1 results in decreased Mash1 expression, a known requirement for dopaminergic neuronal differentiation.

\section{Materials and Methods}

Targeted deletion of Id2. Homologous recombination-based gene targeting in embryonic stem (ES) cells was used to inactivate the Id2 locus in the murine $\mathrm{C} 57 \mathrm{BL} / 6$ strain. The $I d 2$ targeting vector contained the neomycin phosphotransferase resistance gene driven by the thymidine kinase promoter located immediately $5^{\prime}$ from the third exon of the endogenous $I d 2$ gene. Homologous recombination was verified in resistant clones using Southern blot analysis with presence of the mutant allele resulting in a $3 \mathrm{~kb}$ reduction in size of the $I d 2$ locus as the result of replacement of exons 1 and 2 of the $I d 2$ locus by the targeting cassette. C57BL/6 mice were then outbred into a CD1 background to produce a mixed strain and maintained on a diet containing an antibiotic (Septra, Harlan) and breeding was enhanced with a high-fat reproductive supplement (Love-Mash, Bio-Serv). Genotyping of mice was conducted with the following primers: CAA AAC TGT AGC CCT CTG AG, AGG CGC CAG TCT GCT TCT TGT AAC, and TAG CCT GAA GAA CGA GAT CAG CAG, which identify both the WT and mutant allele, with hemizygous mice generating both bands.

Tissue harvest, sectioning, and cell quantitation. Brains were perfusionfixed and dissected followed by either paraffin embedding or preparation for cryosectioning by sucrose protection and embedding in OCT media. Serial histological sections were obtained from $I d 2^{-/-}$and WT littermate controls or age-matched nonlittermate controls as indicated in the text. For evaluation of $\mathrm{OB}$ laminar structure, paraffin sections were stained with hematoxylin and eosin. For area measurements, multiple serial sections from $I d 2^{-/-}$and WT littermate controls were aligned and analyzed. Digital images were obtained using a compound microscope and digital camera (Olympus), and the area of each aligned section was quantified using image analysis software (Imagepro 5.1).

To determine the concentration of immunostained cells within the GCL and PGL, we first identified corresponding histological sections from $I d 2^{-1-}$ and WT mice at three rostrocaudal levels evenly spaced at $\sim 100 \mu \mathrm{m}$ intervals beginning at the most rostral section in which the accessory $\mathrm{OB}$ was not visible. We counted immunostained cells per unit area in corresponding sections on the medial side of the OB using a defined $100 \mu \mathrm{M}^{2}$ grid generated by image analysis software. No fewer than eight sections for each of six animals per genotype were analyzed. Statistical significance was determined using a two-tailed Student's $t$ test with a threshold $p$ value of 0.05 .

Anosmia analysis. A buried food paradigm was used as described (Harding et al., 1978). A single pellet of a high-fat food supplement used to rear Id $2^{-{ }_{-1}}$ mice (Love Mash Reproductive Diet; Bioserve) was buried in a corner $3 \mathrm{~cm}$ below the surface of bedding in a clean cage. The mice were fasted for $16 \mathrm{~h}$ before a set of trials. For each trial the mouse was placed in the center of the cage and given a maximum of $5 \mathrm{~min}$ to find the pellet of food. Mice were considered to have found the food once they excavated and made physical contact with the food pellet. To ensure that memory did not play a role in the test, the pellets for the second and third trials were buried in different corners of the cage at 5 and $1 \mathrm{~cm}$ depths, respectively. For the fourth trial the food was buried in the center of the cage at a depth of $3 \mathrm{~cm}$. If the food had not been found at the end of $5 \mathrm{~min}$, the trial was terminated. Data were analyzed for significance using Student's $t$ test.

Olfactory discrimination. Olfactory discrimination analysis was performed as previously described (Gheusi et al., 2000). Briefly, $15 \mu \mathrm{l}$ of vanilla-scented essential oil diluted 1:10,000 in water was put on filter paper and placed at one end on the floor of the animal's home cage. An identical filter paper with $15 \mathrm{ml}$ of sterilized water was placed on the opposite end of the cage as a control. A habituation-dishabituation task was performed in which vanilla was presented for five successive trials of $3 \mathrm{~min}$ each separated by $15 \mathrm{~min}$ intervals. On the sixth trial, the mouse was exposed for $3 \mathrm{~min}$ to diluted orange scented oil just as in the vanilla trials. Mice were considered to be investigating the odor whenever their noses were $1 \mathrm{~cm}$ or less from the filter paper. Data were analyzed for significance using the Mann-Whitney-Wilcoxon rank-sum test.
Immunohistochemistry. Immunochemistry was performed on either paraffin embedded or cryopreserved sections as required by specific antibodies. All paraffin-embedded sections were analyzed following antigen retrieval using $0.1 \mathrm{~m}$ citrate buffer unless otherwise specified. Mature olfactory granule and periglomerular neurons were identified using antiNeuN (Millipore Bioscience Research Reagents) antibody. Adult born neuronal subtypes were labeled using anti-calretinin (CR) (Novus) and anti-TH (Millipore Bioscience Research Reagents) antibodies. Astroglial lineages were stained using anti-GFAP (Dako) antibody and oligodendroglial lineages were identified by reactivity to anti-Olig2 or anti-O4 (Millipore Bioscience Research Reagents) antibodies. Biotinylated secondary antibodies include anti-mouse and rabbit (Vector Laboratories) antibodies. For fluorescent labeling of frozen sections antigen retrieval was performed using $0.2 \%$ Triton in PBS. For immunofluorescence, neuroglial subtypes were identified with anti-Tuj1 (Promega) antibodies and antibodies that recognize NeuN, GFAP, CR, and TH as described above. Migrating neuroblasts were labeled with anti-Dcx (Abcam) antibody. Fluorescent secondary antibodies include mouse and rabbit 555 and 488 (Alexa Fluor). Paraffin sections were counterstained with hematoxylin and fluorescent stains with Hoechst dye (Sigma).

5-Bromo-2'-deoxyuridine treatment and neural progenitor cell analysis in the subventricular zone and rostral migratory stream. Cell quantification of neural progenitor cells in the SVZ and newborn neuroblasts in the RMS were evaluated by differential 5-bromo-2'-deoxyuridine (BrdU) retention as previously described (Morshead and van der Kooy, 1992; Morshead et al., 1998). To identify SVZ born migrating neuroblasts, WT and $I d 2^{-1-}$ mice were injected intraperitoneally with $\mathrm{BrdU}(80 \mathrm{mg} / \mathrm{kg})$ twice daily for $4 \mathrm{~d}$ and tissues were harvested on day 6 . Cells were quantified from sagittal sections in three locations including the vertical, horizontal, and elbow sections on the RMS as previously described by Martoncíková et al. (2006) and expressed as total number of positive cells in each section compared with WT controls. To interrogate only SVZ stem cells (type-B cells) (Doetsch et al., 1999), mice were injected as above twice daily for $12 \mathrm{~d}$ and left for an additional $16 \mathrm{~d}$ before sacrifice and histological preparation. Sequential sagittal sections were costained for GFAP (Dako) and BrdU (Novus). Type-B cells were identified as BrdU/ GFAP double-positive as opposed to $\mathrm{GFAP}^{+} / \mathrm{BrdU}^{-}$astrocytes.

Proliferation and apoptosis analysis. Neural precursor cells were explanted from the brains of postnatal mice between 1 and $3 \mathrm{~d}$ of age and propagated as described (Reynolds and Weiss, 1992, 1996). For the evaluation of cell growth, 20,000 cells/well were plated in ultra-low binding 24 well plates (Corning). Cell numbers were quantified using a hemacytometer at 2, 4, 6, and $8 \mathrm{~d}$ following plating from three separate wells. To determine the cell cycle distribution of WT and $I d 2^{-/-}$cells, primary neurospheres were dissociated and stained with propidium iodide (PI), and quantified using cell cycle analysis software (Modfit). For in vitro BrdU incorporation cells were plated $24 \mathrm{~h}$ before the addition of $1 \mathrm{mg} / \mathrm{ml}$ $\mathrm{BrdU}$ directly into proliferation media. At specific time points cells were dispersed and BrdU labeling was conducted following pretreatment with $2 \mathrm{~N} \mathrm{HCl}$ using a FITC-conjugated BrdU primary antibody (eBiosciences) followed by detection using flow cytometry. To measure sphere size cells plated in $10 \mathrm{~cm}$ Petri dishes were photographed at indicated time points and sphere area was measured using image analysis software (ImagePro). To evaluate apoptosis in sphere cultures, trypsinized single cell suspensions were stained using the 7 -amino-actinomycin D and Annexin-V Kit per manufacturer's recommendations (Guava-Nexin; Guava Technologies). Analysis of apoptosis in adherent differentiating cells were quantified by examination of chromatin condensation by Hoechst 33342 staining (Sigma) combined with chromatin fragmentation identified by terminal deoxynucleotidyltransferase-mediated dUTP nick end-labeling (TUNEL) (Roche) as previously described (Andres-Barquin et al., 1999). $t$ Test analysis was performed as above.

Luciferase assays. Cultured neurospheres were cotransfected using adenovirus-assisted transfection for increased efficiency. Empty adenoviral vectors or $I d 2$ adenovirus, constitutively activated Notch 1 (NICD1) (generously provided by Dr. Lucy Liaw, Maine Medical Center Research Institute, Scarborough, ME), Hes1-reporter and renilla normalization plasmids were cotransfected into $1 \mathrm{e}^{6}$ dispersed neural stem cells using Fugene (Roche). Cells were allowed to proliferate for $48 \mathrm{~h}$ after transfec- 

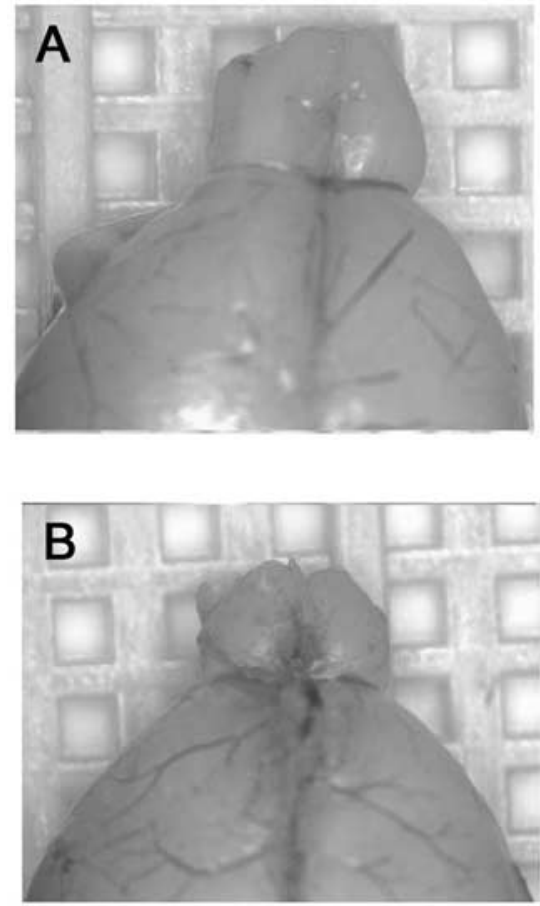
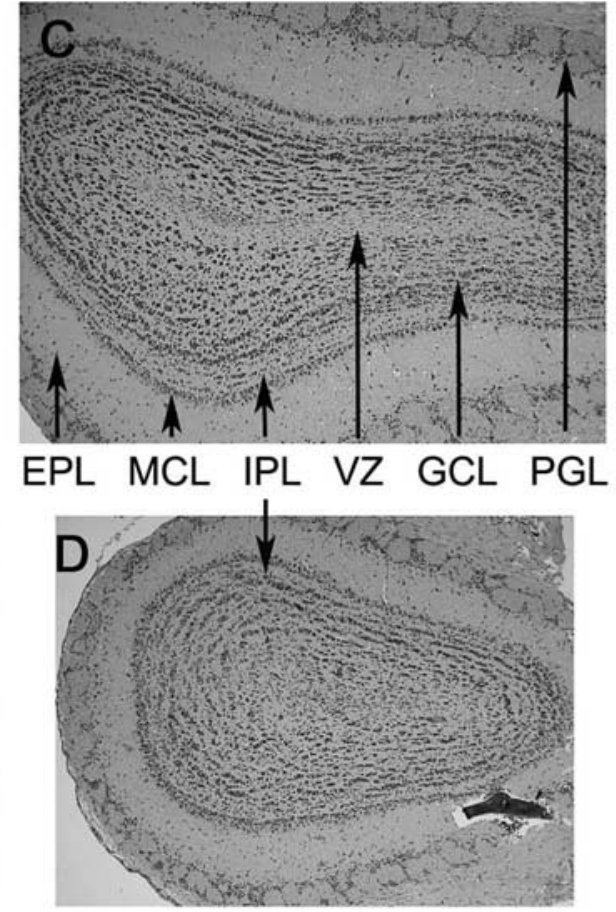
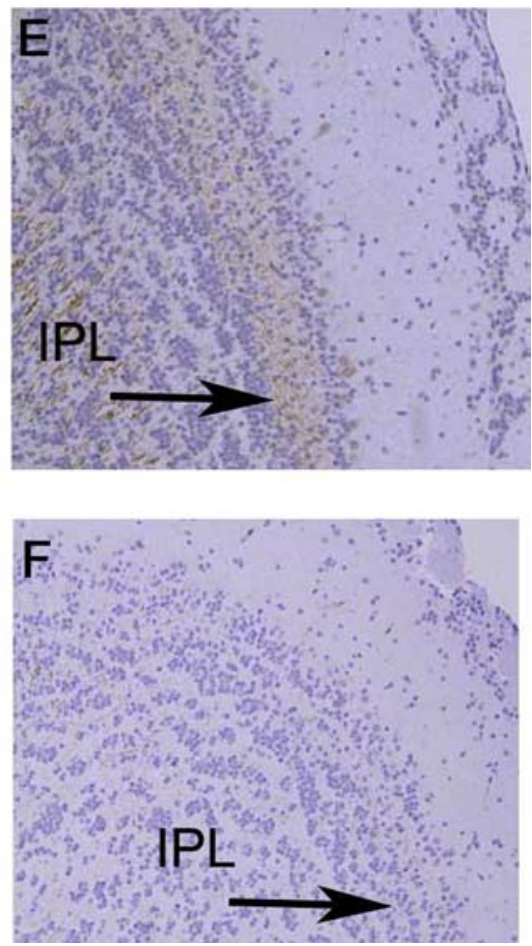

Figure 1. Id $2^{-1-}$ mice have a diminished olfactory bulb. $A, B$, Micrographs of representative gross morphology of WT $(A)$ and $/ d 2^{-1-}(B)$ brains. $C, D$, Morphometrically aligned coronal sections stained with hematoxylin and eosin [arrows denote PGL, external plexiform layer (EPL), mitral cell layer (MCL), IPL, granular cell layer (GCL), and ventricular zone (VZ)]. $\boldsymbol{E}, \boldsymbol{F}, \mathrm{Immunohistochemical}$ evaluation of OB histologic sections from WT $(\boldsymbol{E})$ and $/ d 2^{-\prime-}(\boldsymbol{F})$ mice for neurofilament expression visualized by brown DAB staining and hematoxylin counterstain. Arrows indicate location of IPL, original magnification $40 \times$.

tion, harvested, and luciferase production determined and normalized to renilla (Dual-Luciferase Assay; Promega).

Real-time PCR. Total RNA was collected from WT or Id $2^{-/-}$neurospheres growing in proliferation conditions pretreated with DNAase1 (Promega) and reverse transcribed using iScript reverse transcription mix (Bio-Rad). Samples incubated without reverse transcriptase were included as negative controls. Resultant cDNA was evaluated by quantitative RT-PCR (QT-PCR) for detection of Hes1 transcript (primers available on request) using the iCycler thermocycler (Bio-Rad). PCR products were detected by incorporation of SYBR green (Bio-Rad) and authenticated by melt-curve and gel electrophoresis. Threshold cycle numbers during the log-phase of amplification were normalized to the expression of $\beta$-actin and cyclophilin.

Western blotting. Neurosphere lysates were collected and triturated into chilled lysis buffer [ $(150 \mathrm{~mm} \mathrm{NaCl}, 50 \mathrm{~mm}$ Tris, pH 8.0; $1 \%$ Triton $\mathrm{X}-100)$ ] supplemented with $2.5 \%$ protease inhibitor mixture (Sigma). Protein was quantified using a modified Bradford assay (Bio-Rad) and 60 $\mu \mathrm{g}$ of total protein precleared of insoluble material by centrifugation was analyzed on $15 \%$ acrylamide gels. Blots were probed with anti-Id2 (Santa Cruz Biotechnology), anti-Hes1 (Millipore Bioscience Research Reagents), or anti-Mash1 (Millipore Bioscience Research Reagents) antibodies. Protein loading will be controlled by normalization to $\beta$-actin (Sigma).

Chromatin immunoprecipitation. Input material for chromatin immunoprecipitation assays included total genomic DNA from WT and $I d 2^{-/-}$cultured neurospheres in proliferation medium collected during steady-state log-phase growth $48 \mathrm{~h}$ after dispersion. Following crosslinking in $1 \%$ formaldehyde for $15 \mathrm{~min}$, cells were collected, and genomic DNA was sheared to an average size of 500 bp using a sonicator. Immunoprecipitation was performed with $5 \mu \mathrm{g}$ of a polyclonal anti-Hesl antibody (Millipore Bioscience Research Reagents) overnight. Cross-links were reversed at $65^{\circ} \mathrm{C}$ for $4 \mathrm{~h}$, and DNA was collected by phenol-chloroform extraction and ethanol precipitation. PCR analysis was conducted using primers designed to frame multiple E-Boxes known to mediate Hes1 auto-inhibition (Takebayashi et al., 1994; Hirata et al., 2002). Primer sequences specific to the murine Hes1 promoter are 5'-TTGATTGACGTTGTAGCCTCCGGT (sense), 5'-GGCTCGTGTGAAACTTCCCAAACT (antisense) resulting in the amplification of a 175 bp product. Primer sequences specific to the Mash1 promoter are 5' TGGTCAGGCCATCACGACATTGTA (sense), 5' TCCTTGGCTTCTGCTTTGGTTCCT (antisense) resulting in the generation of a 225 bp product.

\section{Results}

\section{Diminished olfactory bulb size in $I d 2^{-/-}$mice}

Our laboratory has studied the role of $I d$ genes in CNS development (Yun et al., 2004). Although $I d 2^{-/-}$mice have no obvious developmental phenotype, we and others observed defects in lactation and hematopoiesis that are easily detectable in adult animals [unpublished data (Yokota et al., 1999; Mori et al., 2000)]. Upon analysis of the brains of adult $I d 2^{-/-}$mice, we noted an obvious reduction in the size of the $\mathrm{OB}$ of $I d 2^{-/-}$adult mice compared with WT littermates (Fig. 1A,B) (Yokota, 2001). We quantitated the area of multiple morphometrically aligned histological sections at specific rostro-caudal locations (described in Materials and Methods) to evaluate this apparent difference and observed that $I d 2^{-/-}$mice have a significant reduction in the size of the $\mathrm{OB}$ as measured in coronal sections (supplemental Fig. $1 \mathrm{~A}$, available at www.jneurosci.org as supplemental material). These mice, however, do not have a significant change in overall brain mass relative to total body mass (supplemental Fig. $1 B$, available at www.jneurosci.org as supplemental material).

The adult $\mathrm{OB}$ is a highly ordered structure with a discrete laminar organization of individual neuronal cell types. The afferent nerve fibers emanating from olfactory receptor neurons converge on multiple glomeruli and synapse with dendrites from second order tufted and mitral cells whose axons project directly to the pyriform area of the olfactory cortex (for review, see Shep- 

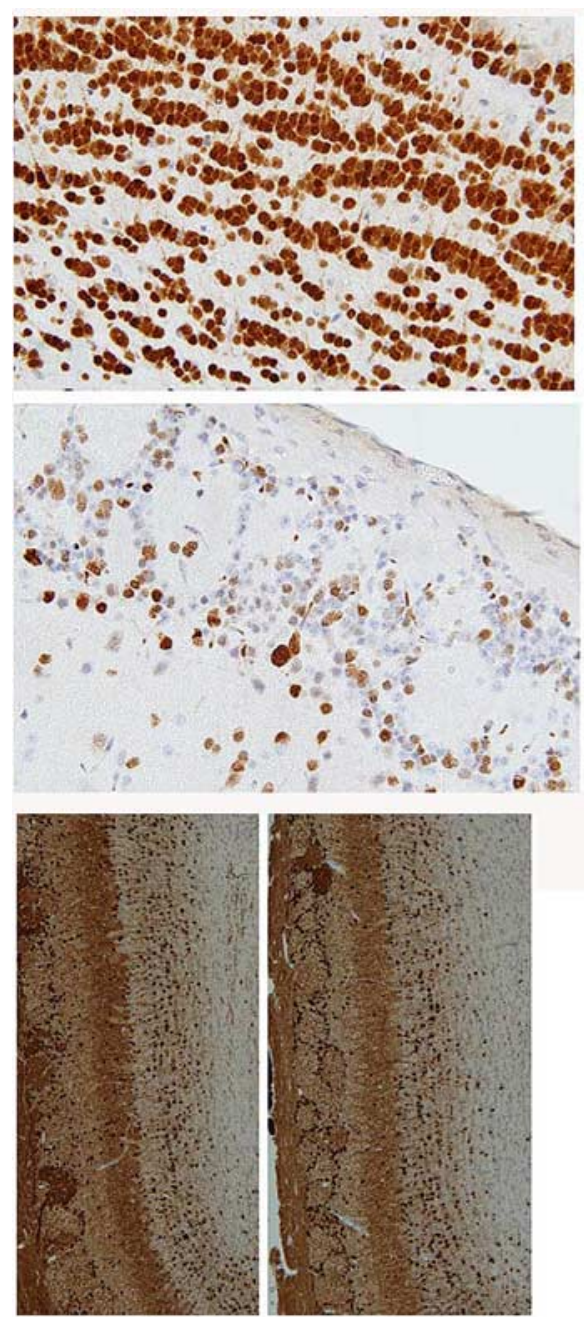
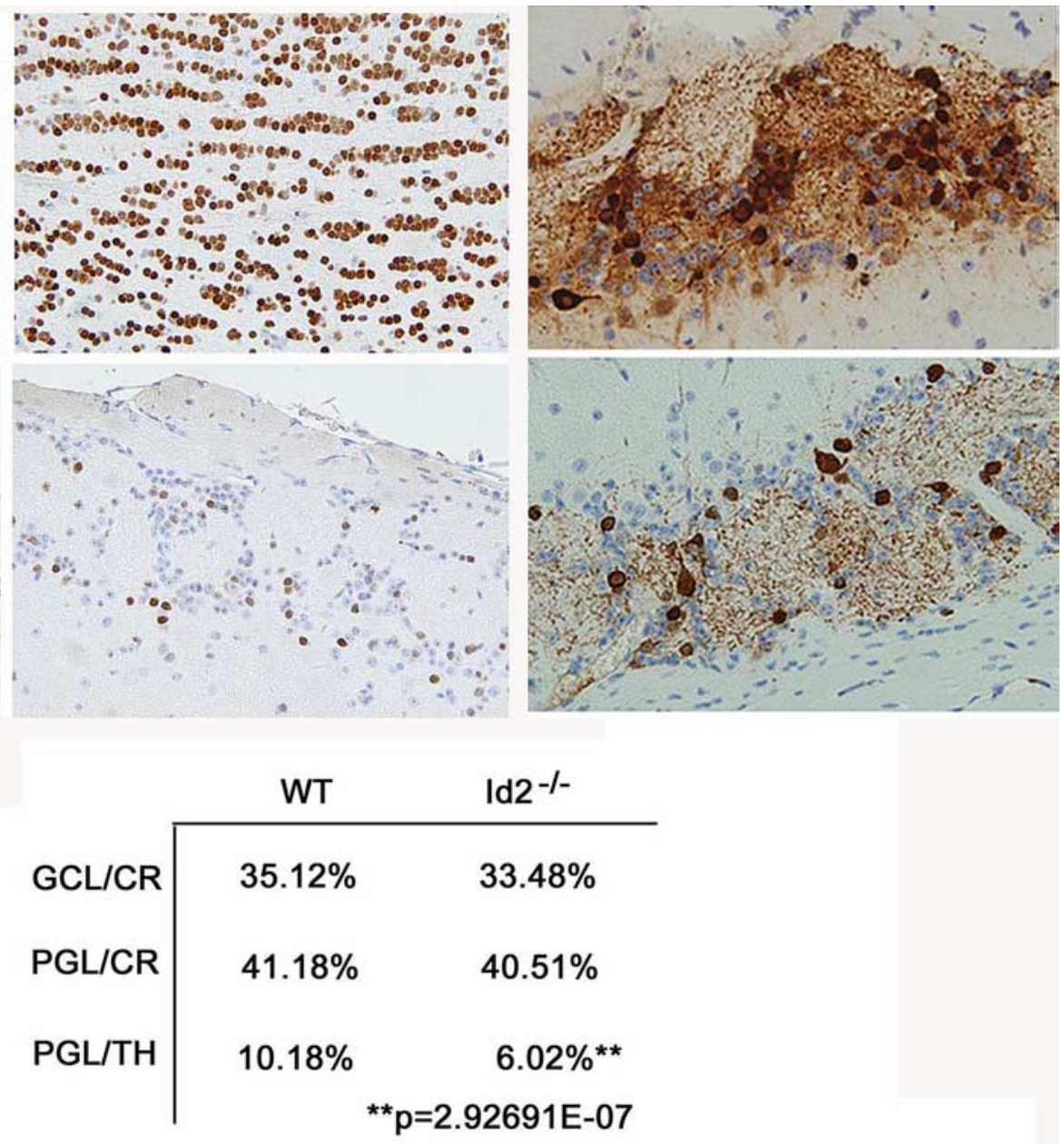

Figure 2. Reduced olfactory bulb size is the result of decreased numbers of newborn neurons. Immunohistochemical analysis of total neurons using NeuN antisera to evaluate coronal sections of the 0B GCL and PGL in WT and $/ d 2^{-/-}$mice. [(A)WT GCL, (B) KO GCL, (C)WTPGL, (D) KOPGL, $100 \mu \mathrm{M}^{2}$ areas, $40 \times$ magnification $\left.\left.n=12\right)\right]$. $\boldsymbol{E}, \boldsymbol{F}$, TH staining of the PGL and GCL in WT $(\boldsymbol{I})$ and $/ d 2^{-/-}$ (J). $\mathbf{G}, \boldsymbol{H}$, Coronal sections stained for CR and counterstained with hematoxylin in WT (G) and $/ d 2^{-/-}(\boldsymbol{H})$ mice. I, Quantitation of CR and TH expressing cells from serial sections in WT and $/ d 2^{-/-}$ mice ( $n=3$ per group). $\mathrm{CR}+/ \mathrm{GCL} p<0.68, \mathrm{CR}+/ \mathrm{PGL} p<0.76$, $\mathrm{TH}+/ \mathrm{PGL} p<4.32 \mathrm{E}-08$, $\mathrm{TH}+/ \mathrm{GCL}$ cells occurred below quantifiable levels.

herd, 1998). Adult born granular neurons in the PGL and GCL modulate the activity of this afferent pathway (Mori and Shepherd, 1994; Shepherd et al., 2007). We undertook a histological analysis of the $\mathrm{OB}$ in WT and $I d 2^{-1-}$ mice to characterize the cellular architecture of these structures. Sections stained with hematoxylin and eosin revealed that the $\mathrm{OB}$ of $I d 2^{-/-}$mice retained most of the typical laminar structure of the OB but had an internal plexiform layer (IPL) that was reduced in size and disorganized (Fig. 1C,D).

Neuronal fibers of the IPL, which is its defining histological characteristic, are thought to represent both dendrodendritic arborizations of granular neurons projecting onto mitral cells and concentric afferent fibers from both tufted and mitral cells (Mori and Shepherd, 1994). We used intermediate neurofilament immunohistochemistry to highlight the IPL in WT and $I d 2^{-/-}$ mice and found an extensive loss of fibers within the IPL of $I d 2^{-1-}$ mice (Fig. $1 E, F$ ). Granular neurons, mitral cells, and tufted cells are thought to project fibers into the IPL (Shepherd, 1998). We found that $I d 2^{-/-}$mice had normal numbers of mitral and tufted cells (data not shown), and therefore we interpret these findings to suggest that the reduced overall size of the $\mathrm{OB}$ most likely results from a loss of granular interneurons.
Ongoing neurogenesis in the adult replenishes granular interneurons of the GCL and PGL of the OB. Throughout life the OB is characterized by the production of newborn granular interneurons emanating from the SVZ and ongoing apoptosis of postmitotic OB interneurons. Neural progenitor cells persist in the adult $\mathrm{SVZ}$ and give rise to neuroblasts that migrate to the $\mathrm{OB}$ and differentiate into mature GCL and PGL interneurons. To further characterize the reduced size of the $\mathrm{OB}$ in $\mathrm{Id} 2^{-/-}$mice, we estimated the numbers of mature interneurons, astroglia, and oligodendroglia in the adult $\mathrm{OB}$. We used immunohistochemical detection of NeuN to identify interneurons of the GCL (Fig. 2A,B) and PGL (Fig. 2D,E), GFAP to identify astroglia (supplemental Fig. $2 A, C$, available at www.jneurosci.org as supplemental material), and Olig2 to identify oligodendroglia (supplemental Fig. $2 B, C$, available at www.jneurosci.org as supplemental material) in the $\mathrm{OB}$ of WT and $I d 2^{-/-}$mice. We found a significant reduction in the concentration of NeuN-positive cells in the GCL of $I d 2^{-/-}$mice compared with the GCL of WT mice (Fig. $2 A, B$ ), and an even greater reduction was noted in the PGL of $I d 2^{-1-}$ mice (Fig. 2C,D). Interestingly, we also detected an increased percentage of astroglia within the GCL of $I d 2^{-/-}$animals (supplemental Fig. $2 A, C$, available at www.jneurosci.org as supple- 


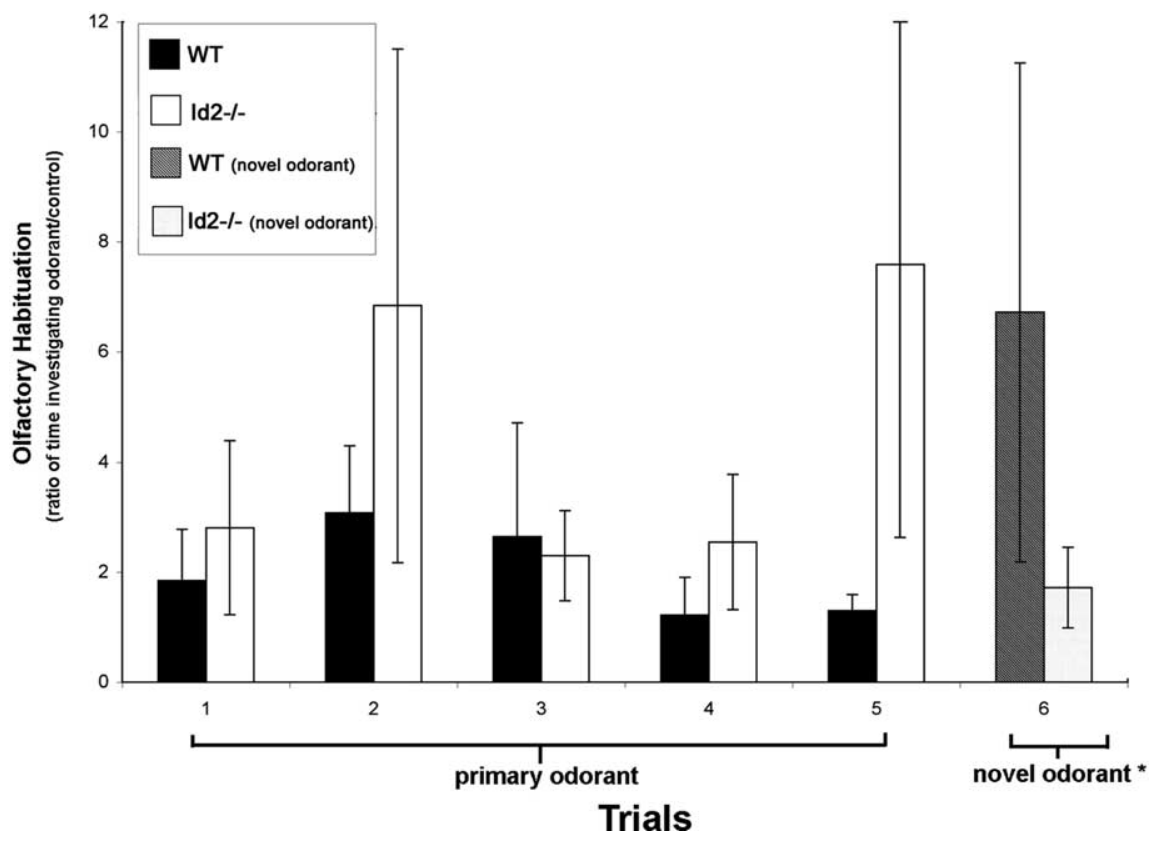

Figure 3. Altered olfaction in $I d 2^{-1-}$ mice. Olfactory discrimination was analyzed using a habituation-dishabituation paradigm (Gheusi et al., 2000). To evaluate habituation, mice ( $n=5$ per genotype) were presented with a primary odorant on five consecutive trials at 30 min intervals, and the time spent investigating the location of an odorant was designated as a ratio of this duration compared with the time spent investigating a control of unscented water. For the sixth trial, a novel odorant was substituted for the primary odorant. The ratios reported represent the average of two independent experiments performed in triplicate. Error bars represent SEM. Mann-Whitney-Wilcoxon rank-sum test was performed on the differences between the responses of WT and $I d 2^{-I-}$ mice to the presentation of the novel odorant. $W=52(p<0.04)$.

mental material), although Olig2 staining did not reveal a significant difference in the representation of oligodendroglia (supplemental Fig. 2 B, C, available at www.jneurosci.org as supplemental material).

\section{Loss of $I d 2$ results in a specific depletion of PGL dopaminergic neurons}

Recent evidence has indicated that as many as 21 neurochemically distinct subtypes of interneurons exist within the adult $\mathrm{OB}$ (Parrish-Aungst et al., 2007). To further define the role of $I d 2$ in the biology of adult-born OB neurons within both the GCL and PGL, we evaluated two distinct cell populations in these layers which are highly dependent on adult neurogenesis (Lemasson et al., 2005; De Marchis et al., 2007). GABAergic inhibitory granule cells within both the GCL and PGL can be identified by expression of the calcium binding protein, calretinin (CR). The second adult-born neurons residing within the PGL are dopaminergic and can be identified by the expression of $\mathrm{TH}$, the rate limiting enzyme in the synthesis of dopamine (for review, see Bovetti et al., 2007). We used the expression of CR and TH to identify these different cell types for quantitation. Immunohistochemical analysis revealed a $40 \%$ depletion of TH-positive neurons in the PGL accompanied by an observable reduction in TH-positive neuropil (Fig. $2 E, F, I$ ). This occurs in the absence of significant difference in the numbers of CR-positive neurons in the GCL and the PGL of WT and $I d 2^{-/-}$mice (Fig. $2 G-I$ ). We detected only very rare $\mathrm{TH}$-positive neurons within the GCL of WT or $I d 2^{-/-}$mice (data not shown). These data indicate that $I d 2$ is important for maintenance of a normal population of dopaminergic OB PGL neurons and is not required to maintain normal levels of the CR-positive nondopaminergic neuronal subtypes.

\section{Altered olfaction in $\mathrm{Id} 2^{-/-}$mice}

We tested olfactory sensitivity and discrimination in $I d 2^{-/-}$mice seeking to identify a physiological impact of $I d 2$ loss. Using a hidden reward challenge, we examined olfactory sensitivity and found that it was not different in WT and $I d 2^{-/-}$ mice (data not shown) (Galton et al., 2007). To examine olfactory discrimination we used a habituation-dishabituation paradigm (Gheusi et al., 2000). In this model WT mice performed as expected with their initial interest in a primary odorant evidenced by the increased time spent examining the odorant during trials 1, 2, 3 (Fig. 3) decreasing over time (Fig. 3, trials $3,4,5)$ as mice habituated to the stimulus (Fig. 3). Introduction of a different odorant following habituation resulted in the anticipated result of "dishabituation" in WT mice. This is reflected in the time spent investigating the new odorant (Fig. 3, trial 6) compared with the time spent investigating the primary odorant at the end of the habituation study (Fig. 3, trial 5). We found that $I d 2^{-/-}$mice failed to habituate to the primary stimulus (Fig. 3 , trials 1-5) and showed no demonstrable dishabituation after the introduction of the novel odorant (Fig. 3, trials 5, 6). These data, in combination with our histologic findings, indicate that $I d 2^{-/-}$mice have an intact primary sensory apparatus; however, they are defective in olfactory memory and discrimination. These functional characteristics are consistent with the proposed function of sensory modulation for granular cells of the OB (Shepherd et al., 2007).

\section{Loss of Id2 does not affect cell survival in vivo}

The decreased numbers of dopaminergic granular neurons in the $\mathrm{OB}$ (Fig. 2) and the olfactory deficit that these animals exhibited (Fig. 3) provide strong evidence of a role for $I d 2$ in the maintenance of cellular homeostasis, since these neurons are known to die throughout life and require replacement by ongoing neurogenesis (Petreanu and Alvarez-Buylla, 2002). Previous studies conducted in our laboratory have demonstrated a role for Id proteins in mediating apoptosis (Florio et al., 1998; AndresBarquin et al., 1999). We sought therefore to characterize neuronal OB cell death in the GCL and PGL of adult $I d 2^{-/-}$mice (supplemental Fig. $3 A-D$, available at www.jneurosci.org as supplemental material). For this analysis we used the TUNEL assay to examine serial histological sections of OB from WT and $I d 2^{-/-}$mice for evidence of apoptosis. We found no difference in the number of apoptotic nuclei in the GCL (supplemental Fig. $3 A, B, E$, available at www.jneurosci.org as supplemental material) and PGL (supplemental Fig. 3C,D,E, available at www. jneurosci.org as supplemental material) of WT and $I d 2^{-/-}$mice. In fact, quantitation in serial sections, suggested a slight decrease in the number of apoptotic cells in these OB regions of $I d 2^{-1-}$ mice consistent with the role of $I d 2$ as a proapoptotic gene (supplemental Fig. 3E, available at www.jneurosci.org as supplemental material) (Florio et al., 1998). We sought to characterize cell death in the RMS to determine the level of apoptosis in migrating neuroblasts. As expected we observed TUNEL-positive cells in 
histologic sections of the $\mathrm{OB}$ from both WT and $I d 2^{-/-}$mice (supplemental Fig. $3 F, H$, available at www.jneurosci.org as supplemental material), however, we found no evidence of apoptosis within the RMS in these same histologic sections (supplemental Fig. 3G,I, available at www. jneurosci.org as supplemental material). These data indicate that the loss of $I d 2$ does not affect the size of the adult OB by enhancing cell death in vivo.

\section{Altered olfactory neurogenesis in adult Id $2^{-/-}$mice}

We sought to examine further olfactory neurogenesis in adult $I d 2^{-/-}$animals. Neuronal precursor type-C cells in the SVZ can be differentiated from long-term repopulating B-cells based on their cell cycle times (Morshead and van der Kooy, 1992; Morshead et al., 1998). To identify these cells, we inoculated mice for 7 consecutive days with BrdU and used immunohistochemical analysis to identify BrdU-positive, rapidly dividing, type-C cells within the SVZ, RMS, and into the OB. Type-B cells within the SVZ can be identified based on long-term BrdU retention identified by immunohistochemical analysis $16 \mathrm{~d}$ following this same $7 \mathrm{~d}$ inoculation protocol (Merson et al., 2006). We were not able to detect differences in the numbers of type-C cells in the SVZ (Fig. $4 A-C)$. Double labeling with GFAP and long-term BrdU incorporation was used to detect type-B cells in the SVZ (data not shown), which are widely thought to be the most primitive neural stem cells (Doetsch et al., 1999). In this case, while rare double-positive cells were detectable
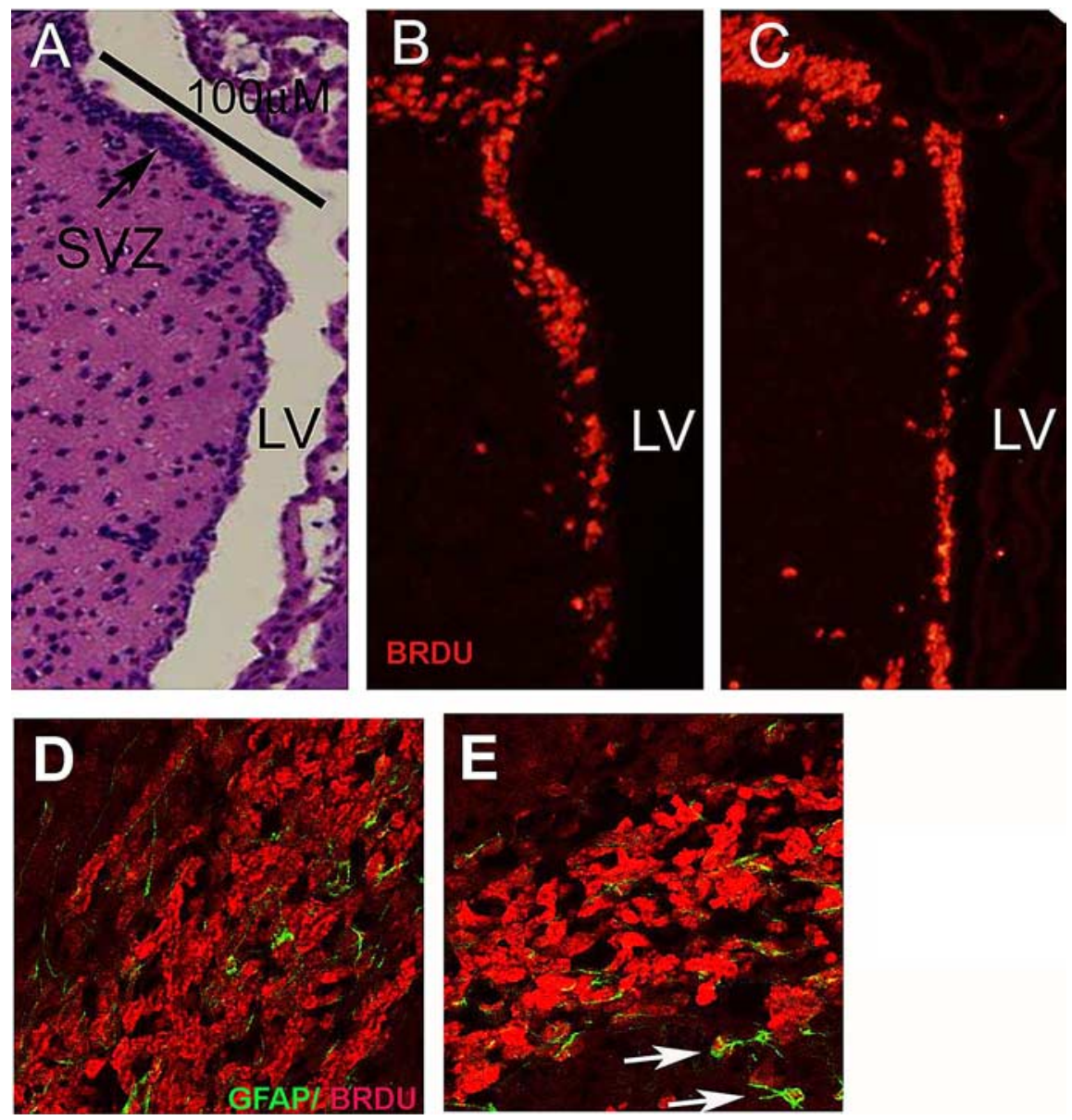

Figure 4. Id $2^{-1-}$ mice retain normal numbers of neural progenitor cells, but the RMS is reduced in size and disorganized. $\boldsymbol{A}-\boldsymbol{C}$, Multiple sections taken from short-term BrdU pulsed animals were immunostained to identify BrdU-positive cells from a morphometrically matched linear surface along the anterior wall of the SVZ identified in the H\&E section by a black bar $(\boldsymbol{A})$. $\boldsymbol{B}, \boldsymbol{C}$, Identification of BrdU-positive cells (red) in tissue from WT $(\boldsymbol{B})$ and $/ d 2^{-/-}$mice (C). D, E, Confocal images of BrdU/GFAP double-labeling of the RMS in WT $(\boldsymbol{D})$, and $/ d 2^{-/-}(\boldsymbol{E})$. $\boldsymbol{E}$, Arrows indicate atypical locations for a GFAP/BrdU double-positive cells proximal to the RMS in a representative $I d 2^{-/-}$histologic section. In $\boldsymbol{D}$ and $\boldsymbol{E}$, the red fluorescence corresponds to BrdU incorporation and green fluorescence corresponds to GFAP expression.

in both WT and $I d 2^{-/-}$mice, they appeared in similar numbers and no change in the population of long-term repopulating cells in $I d 2^{-1-}$ mice could be identified (data not shown). We interpret these findings to indicate that the germinal SVZ compartment containing type-B cells and their progeny was intact in $I d 2^{-/-}$animals and that a decrease in the numbers of type-B cells is not responsible for the OB phenotype we observed.

We observed that although BrdU-labeled cells reach the OB through an intact RMS in $I d 2^{-1-}$ mice, an easily and invariably observed alteration in the architecture of the RMS was detectable. Compared with WT littermates the RMS of $I d 2^{-/-}$mice was characterized by decreased RMS diameter (Fig. 4D,E) (and data not shown), and the appearance of rogue GFAP/BrdU doublepositive cells located proximal to, but outside of the RMS proper (Fig. $4 E$, arrows). To further evaluate the characteristics of migrating type-A cells in the RMS, we used immunofluorescence to detect Dcx (data not shown), which specifically labels migrating neuroblasts (Yang et al., 2004). As expected, in WT animals Dcx labeling reveals elongated cells in an organized migration pattern within the RMS tangential to the SVZ en route to the OB. In $I d 2^{-/-}$animals Dcx staining was much less intense and elongated cells were absent suggesting a loss of both cellular orientation and RMS organization. Also we did not identify the accumu- lation of BrdU-labeled neuroblasts within the RMS (Fig. 4D,E). These findings indicate that while the SVZ produces normal numbers of type-C neuroblasts (Fig. $4 A-C$ ), and apparent alteration in migrating type-A cells occurs resulting in a reduced diameter of the RMS and a loss of the characteristic histological appearance of the RMS.

These observations of an altered RMS and our previous data suggesting that increased numbers of astroglia are present in the $\mathrm{OB}$ (supplemental Fig. $1 A$, available at www.jneurosci.org as supplemental material) led us to more critically examine the possibility that $I d 2$ loss led to increased numbers of astroglia within the $\mathrm{OB}$ at the expense of neuronal populations. We used immunohistochemical analysis of GFAP expression to label mature astrocytes within the $\mathrm{OB}$. We found a dramatic increase in the number of GFAP-positive cells with astrocytic morphology in $I d 2^{-/-}$animals localized to the inner granular and germinal layers of the $\mathrm{OB}$ suggesting that these cells were emanating from the RMS (Fig. $5 A, B$ ). This increase is also obvious in aligned coronal sections of the OB from $I d 2^{-/-}$and WT mice in a histological pattern suggesting their emergence from the RMS (Fig. 5C-F). To extend this observation we used immunohistochemical analysis to examine aligned $\mathrm{OB}$ histological sections prepared from mice that had been killed immediately following a $7 \mathrm{~d}$ BrdU in- 

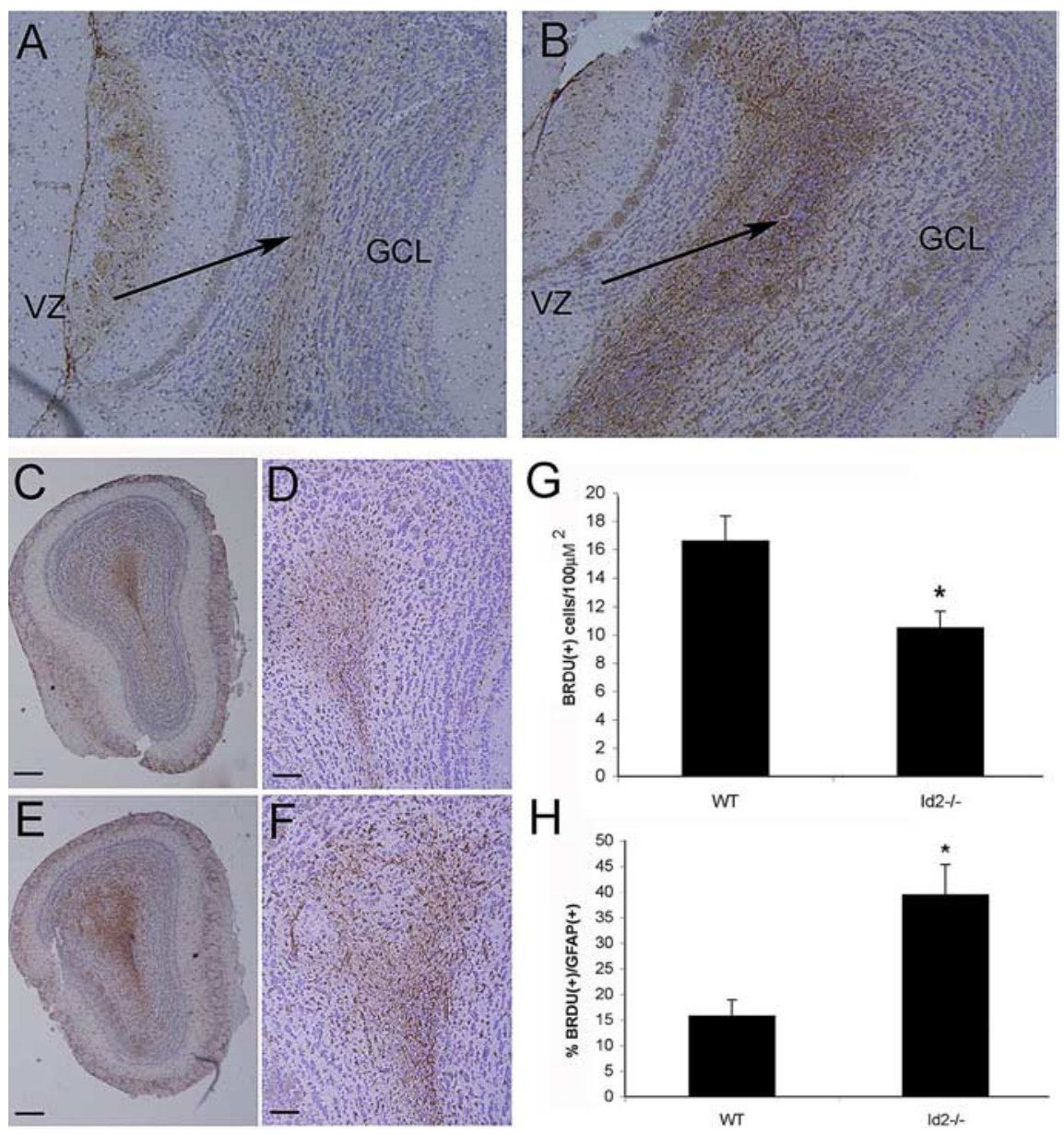

Figure 5. The $I d 2^{-1-}$ olfactory bulb has increased numbers of newborn astrocytes. GFAP immunohistochemical analysis (brown staining) of sagittal $(\boldsymbol{A}, \boldsymbol{B})$ and coronal $(\boldsymbol{C}-\boldsymbol{F})$ histologic sections of WT $(\boldsymbol{A}, \boldsymbol{C}, \boldsymbol{D})$ and $/ d 2^{-/-}(\boldsymbol{B}, \boldsymbol{E}, \boldsymbol{F})$ OB counterstained with hematoxylin. $\boldsymbol{A}, \boldsymbol{B}$ Arrows denote VZ. Original magnification $5 \times$. $\boldsymbol{C}, \boldsymbol{E}$, Original magnification $5 \times$; scale bars, $100 \mu \mathrm{m} . \boldsymbol{D}, \boldsymbol{F}$, Original magnification $20 X$; scale bars, $50 \mu \mathrm{m}$. G, Using immunofluorescence on frozen sections from animals inoculated for $7 \mathrm{~d}$ with BrdU, total BrdU-positive cells were quantified in serial confocal micrographs taken from the $\mathrm{OB}$ of WT and $/ d 2^{-1-}$ mice. $\boldsymbol{H}$, $\mathrm{BrdU} / \mathrm{GFAP}$ double-labeled newborn astrocytes were quantified in multiple fields ( $n=36$ fields per genotype) from serial tissue sections and expressed as a percentage of total cells. Error bars represent SEM (E) $p<0.023 . \boldsymbol{F}, p<0.005$.

oculation regimen for GFAP expression and BrdU incorporation (see Materials and Methods) (Reynolds and Weiss, 1992, 1996). We quantified BrdU single-positive and BrdU/GFAP doublepositive cells within the $\mathrm{OB}$ in multiple sections using confocal microscopy (Fig. 5G,H). Our finding of decreased BrdU-labeled cells within the $\mathrm{OB}$ of $I d 2^{-/-}$mice (Fig. $5 G$ ) suggests that fewer cells born in the SVZ and RMS reach the OB of these mice. Also, we found in $I d 2^{-1-}$ mice a greater percentage of these cells expressed GFAP (Fig. $5 H$ ) suggesting that either enhanced numbers of neuroblasts differentiate into astrocytes or that fewer neuroblasts fated to differentiate into neurons arrive in the $\mathrm{OB}$. These data support a model in which the loss of Id2 in RMS neuroblasts contributes to a cell-fate alteration resulting in increased numbers of astroglia and a diminished neuronal cell population in the OB.

\section{Id 2 regulates growth kinetics and differentiation of cultured neural progenitor cells}

Our in vivo observations support a model by which a normal SVZ produces appropriate numbers of type-C cells, however, an alteration in cell fate during migration in the RMS leads to an increase in the production of $\mathrm{OB}$ astrocytes. An analysis of neural progen- itor growth in vitro under proliferation conditions following dispersion of neurospheres revealed that $I d 2^{-/-}$progenitor cells grew more slowly than cells isolated from WT animals and cultured in an identical manner (Fig. 6A). We used BrdU incorporation quantified by flow cytometry to examine the DNA synthesis at several time points following neurosphere dispersion and plating. We routinely observed that BrdU accumulation was decreased in Id $2^{-1-}$ cells compared with WT cells as early as $24 \mathrm{~h}$ following dispersion (Fig. $6 B)$. We used DNA content flow cytometry to characterize the cell cycle distribution of neurosphere cultures prepared from WT and $I d 2^{-/-}$mice maintained in proliferation conditions. When compared with WT cultures, cultures from $I d 2^{-/-}$ animals demonstrated a decrease in S-phase cells and a corresponding increase in $\mathrm{G}_{0}$ cells $\left(\mathrm{G}_{0}\right.$ : WT $58.57 \%, I d 2^{-/-}$ $73.65 \%$; S-phase: WT $33.37 \%$, Id2 ${ }^{-/-}$ $21.07 \%$ ). Consistent with this observation we also observed a decrease in the average neurosphere size attained by $I d 2^{-/-}$cells (Fig. 6C). To be certain that $I d 2^{-/-}$cells in vitro were not undergoing increased apoptosis we analyzed the expression of Annexin $\mathrm{V}$ in cells cultured in proliferation conditions $24 \mathrm{~h}$ after dispersion. We did not observe any difference between WT and $I d 2^{-/-}$cells in the percentage of apoptotic cells that arose under these conditions (data not shown).

To examine the possibility that premature astroglial differentiation within neurospheres growing in proliferation conditions was the cause of decreased cell proliferation and sphere size in $I d 2^{-/-}$ cultures. For this analysis, neurospheres were dispersed and immediately mounted and fixed on a polylysine coated slide at specific time points after the initiation of the cultures. These cells were then immunostained for GFAP. While GFAP expression is a hallmark of rare type-B cells in vivo, we did not detect expression at the $24 \mathrm{~h}$ time point in WT cells (Fig. 6D), and only minimal expression was detected at the $48 \mathrm{~h}$ time point indicating that type-B cells would not confound our analysis of astroglial differentiation (Fig. $6 E$ ). In support of our in vivo findings that the $\mathrm{OB}$ of $I d 2^{-/-}$mice contained an increased number of astroglial cells (Fig. 5), cultures from $\mathrm{I} d 2^{-1-}$ mice express GFAP at $24 \mathrm{~h}$ after plating in proliferation conditions (Fig. $6 \mathrm{~F}$ ) and at $48 \mathrm{~h}$ significantly more GFAP-positive cells than were present in cultures from WT animals were observable (Fig. 6G). Our finding in these neurosphere cultures of increasing percentages of GFAP-positive cells (Fig. $6 F, G$ ), diminished cellular proliferation, and decreased sphere size suggest that $I d 2^{-1-}$ cells more avidly undergo astroglial differentiation than do comparable cells from WT animals. We interpret our ability to establish neural progenitor cultures from $I d 2^{-/-}$mice as indicating that functional type-B cells must be present. The decreased proliferative rate of these cultures combined with increased numbers of astroglia present under conditions that support proliferation 

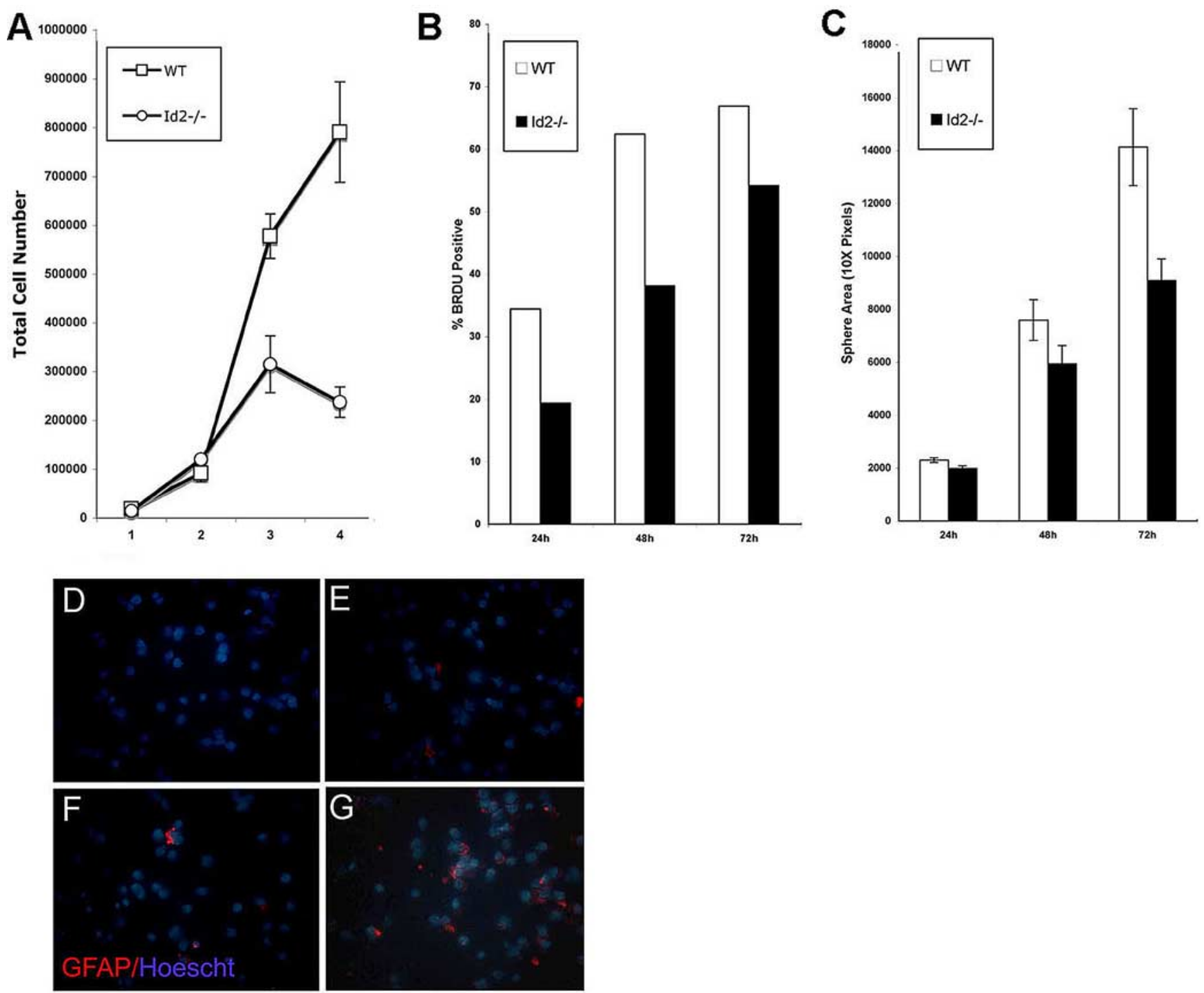

Figure 6. Cultured $/ \mathrm{d} 2^{-1-}$ neural progenitors exhibit altered growth kinetics and premature astroglial differentiation. SVZ cells were explanted from neonatal mice and examined for alterations in growth kinetics in vitro. $\boldsymbol{A}$, Neurospheres were dispersed and cells were plated at an initial density of 20,000 cells in 24 -well plates in triplicate and counted days $1-4 . \boldsymbol{B}$, BrdU (1 mg/ml) was added to neurosphere cultures immediately after dispersion collected at 24,48 , and $72 \mathrm{~h}$ after addition of BrdU. Accumulation of BrdU by WT and $/ d 2^{-/-}$cells was analyzed using flow cytometry. Results representative of three independent experiments are shown. C, Sphere size was measured using image analysis software $48 \mathrm{~h}$ after dispersion. $\boldsymbol{D}-\mathbf{G}$, Neurospheres were dispersed and grown in proliferation conditions for 12 and $24 \mathrm{~h}$ at each time point, cells were dispersed and cytospin cytologic slides of 50,000 cells were immediately prepared. Cytospin preparations were analyzed using GFAP immunofluorescence and Hoechst dye counterstain (D, WT, $24 \mathrm{~h} ; \boldsymbol{E}, \mathrm{WT}, 48 \mathrm{~h} ; \boldsymbol{F}, I d 2^{-\prime-} ; \boldsymbol{G}, 48 \mathrm{~h}$ ).

suggests that astroglia from type-C or type-A progeny, which make up the majority of proliferative neurosphere cultures, differentiate during cultivation (Reynolds and Weiss, 1992).

To evaluate the potential mechanisms of cell fate alterations resulting from the loss of $I d 2$ expression, we explanted neural precursor cells from the SVZ of WT and $I d 2^{-/-}$mice and cultured them as neurospheres. Using in vitro differentiation techniques (see Materials and Methods) we induced these cells to differentiate, observed them for $16 \mathrm{~d}$, and used immunochemistry to evaluate the emergence of cells of the neuronal, astrocytic, and oligodendroglial lineages. We observed a multilayered bed of GFAP-positive cells within three days of establishing these cultures and the presence of both oligodendroglial and neuronal lineages by day seven in culture (data not shown). Although a small decrease in the numbers of neuronal cells in $I d 2^{-1-}$ cultures seemed discernible upon inspection, we were unable to reliably quantify cells in the various lineages of interest because focal regions with a high percentage of differentiated cells were dispersed within large regions with only very positive rare cells.

\section{Regulation of Hes 1 by Id2}

Hes1 is a bHLH transcription factor known to be important for the inhibition of neuronal differentiation, although it is permissive of astroglial differentiation (Nakamura et al., 2000; Hatakeyama et al., 2004). Id2 has recently been demonstrated to specifically inhibit Hes 1 auto-repression by directly binding Hes 1 protein and preventing it from homo-dimerizing and engaging its own promoter (Bai et al., 2007). To determine the effect of Id2 on Hes 1 expression in neural progenitors, we compared the level of Hes1 transcript in cultured neural progenitor cells from both $\mathrm{WT}$ and $I d 2^{-{ }^{-}}$mice in vitro using real-time PCR and found it to be significantly reduced in $I d 2^{-1-}$ mice (Fig. $7 A, D$ ). Also, enhanced expression of $I d 2$ is associated with enhanced expression of Hes 1 protein in this cell type (Fig. $7 B$ ). These findings are 


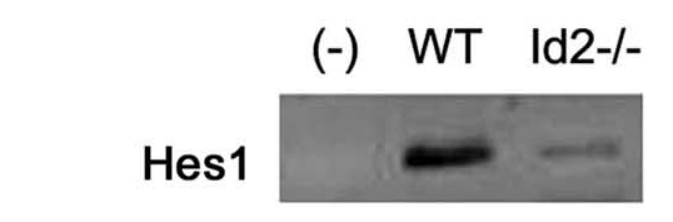

\section{Cyclophilin}
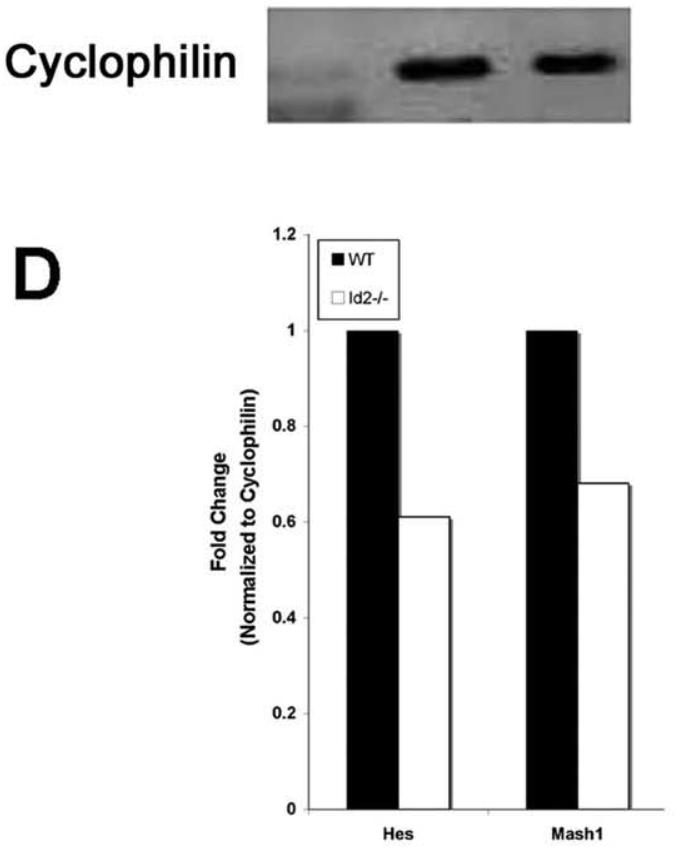

B

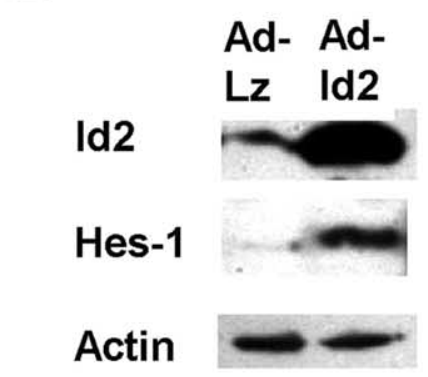

$\mathbf{E}$

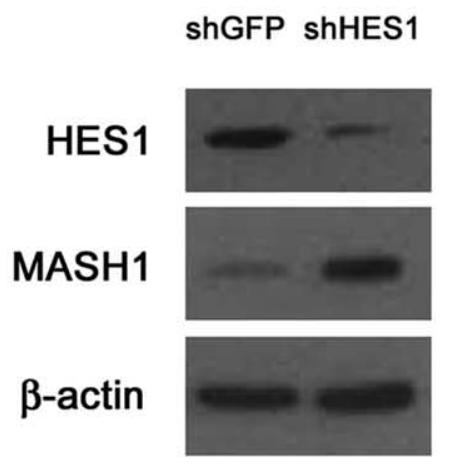

C

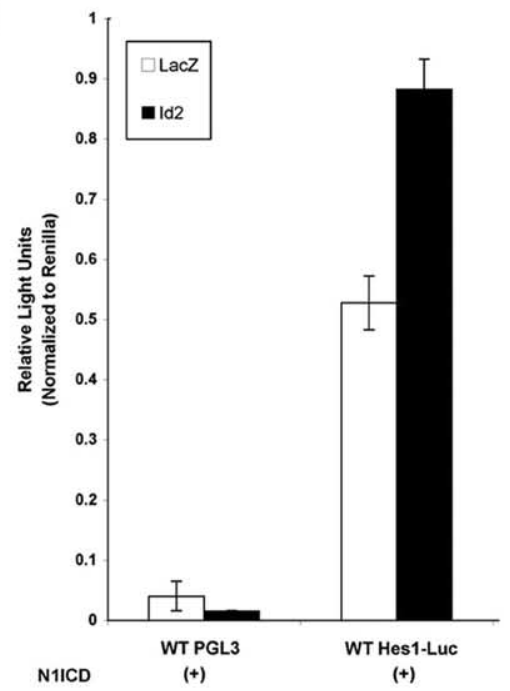

Figure 7. Id 2 regulates the expression and activity of Hes1. $\boldsymbol{A}$, Total RNA was collected from WT and $/ d 2^{-/-}$neural progenitor cells, reverse transcribed, and analyzed for Hes $1 \mathrm{mRNA}$ using RT-PCR. B , Western blot indicating that transient expression of Id2 using adenovirus results in increased expression of Hes 1 protein. $\boldsymbol{C}$, Luciferase reporter assays were conducted using firefly luciferase driven by the Hes 1 promoter. Hes 1 reporter activity was induced by cotransfection with constitutively activated Notch1. Addition of Id 2 adenovirus resulted in increased activity of the reporter compared with the LacZ control virus. D, A representative experiment of real-time PCR analysis of Hes 1 and Mash 1 mRNA levels in cultured neural progenitor cells, from WT and /d2 $-/-$ mice. $\boldsymbol{E}$, Stable cell lines were created by infections with retroviral vectors expressing shRNA directed against the Hes1 or a control virus expressing shRNA directed against eGFP in cultured neural progenitor cells. Western blot indicates that Hes1 knock-down results in increased expression of Mash1.

consistent with the expectation that loss of Id2 would lead to increased auto-repression and a decreased steady state level of Hes 1 mRNA. We extended this observation to evaluate the effect of Id 2 expression in neural progenitors on Hes1 promoter activity. We cotransfected neural progenitors with a luciferase reporter construct that encompasses the entire Hes1 promoter including the site at which Hes1 binding mediates auto-repression (Hirata et al., 2002). Expression from this reporter gene construct in neural progenitors is below detectable levels in the absence of Notch activation (data not shown). We therefore examined the ability of Id 2 to alter Hes 1 promoter activity in the presence of N1ICD, an activated form of Notch1, and found that Hes1 promoter activity was greatly enhanced in the presence of Id2 (Fig. 7C). These data all support strongly the established notion that Id 2 inhibits Hes1 auto-repression (Bai et al., 2007), and raises the important possibility that the lack of Id 2 in neural progenitors in $I d 2^{-/-}$mice leads to enhanced Hes1 mediated inhibition of its targets, including genes that regulate neural differentiation (Manglapus et al., 2004).

Mash1 has been identified as critical to the genesis of dopamineric neurons (Park et al., 2006), and Mash1 is a known direct target of Hes1 repression (Fischer and Gessler, 2007). We therefore examined whether the enhanced transcriptional inhibitory activity of Hes 1 in $I d 2^{-/-}$mice affected expression of the pro- neural transcription factor Mash1 in neural progenitor cells. We found reduced expression of Mash1 mRNA in $I d 2^{-/-}$neural progenitor cells using real-time PCR (Fig. 7D). This suggests that in the absence of Id 2 expression, Hes 1 function is enhanced not only as measured by the auto-repression of its own promoter (Fig. 7D), but also repression of its endogenous targets. To extend this observation we used short-hairpin RNA (shRNA) stably expressed by retroviral vectors to decrease expression of Hes1 in WT neural precursors cells. We detected increased expression of Mash1 protein in these cells, suggesting that endogenous Hes1 expression functions to inhibit transcription of Mash1 (Fig. 7E).

We next sought further evidence of increased Hes1 activity mediating transcriptional inhibition and causing the reduced expression of Hes 1 and Mash1 (Fig. 7D) in Id $2^{-/-}$cells. Our experiments suggested that loss of Id 2 would result in increased Hes 1 auto-repression as well as increased repression of Mash1 (Fig. 7). We conducted ChIP assays to evaluate the binding of Hes1 to target E-Boxes located within its own promoter (Takebayashi et al., 1994), and we detected a robust increase in Hes1 bound this target sequence $I d 2^{-1-}$ neural progenitor cells (Fig. $7 A$ ). This finding provides additional evidence that in $I d 2^{-1-}$ cells increased Hes1 auto-inhibition is responsible for the reduction in Hes1 transcript (Fig. 7A). Next, we examined Hes1 immunoprecipitated chromatin for evidence of increased binding to the 
Mash1 promoter. We identified two N-Box target motifs $[(-3162$ through $-3167)$ and $(-3172$ through -3177$)$ relative to start codon], known target motifs for Hes1 (Iso et al., 2003), adjacent to one another in the $5^{\prime}$ UTR of the murine Mash1 genomic sequence. We designed ChIP primers specific for a 225 bp fragment encompassing these two target sequences. Using these, we were able to amplify this murine Hes1 target motif within the Mash1 promoter only in chromatin immunoprecipitated from $I d 2^{-/-}$neural progenitor cultures by anti-Hes-1 antibody (Fig. $8 \mathrm{~B}$ ). This indicated that both Hes 1 auto-repression and Hes1 mediated Mash1 repression were augmented in $I d 2^{-/-}$cells. Based on these observations, we propose an extension of the model developed by Bai et al. In our model, $I d 2$ remains expressed in a subset of migrating neuroblasts, inhibiting Hes1 mediated transcriptional repression as manifested by both decreased Hes 1 auto-repression as well as decreased inhibition of Mash1 expression. This allows for higher levels of Mash1 expression in cells expressing $I d 2$ contributing to the production of dopamergic neurons (Park et al., 2006). This paradigm indicates a role for $I d 2$ that is incongruous with its widely known function as an inhibitor of tissue specific differentiation (Cai et al., 2000). In this case, $I d 2$ is required for the differentiation of dopaminergic OB PGL neurons (Figs. 2, 8C).

\section{Discussion}

Determination of the molecular basis of cell-fate specification and cellular lineage specific maturation during adult neurogenesis is of critical importance for understanding normal nervous system function and may inform future therapeutic strategies for a variety of disorders, especially neurodegenerative disease (Lim et al., 2007). Using a targeted gene deletion strategy, we have identified a previously unrecognized role for $I d 2$ in maintaining the size and cellular organization of the $\mathrm{OB}$ in adult mice. This is of particular significance because the size of the OB can reflect alterations in the homeostatic mechanisms that balance the death of olfactory neurons throughout life with their replacement by cells originating as multipotent neural progenitor cells in the SVZ. We characterized the decreased size of the OB in $I d 2^{-1-}$ mice, and we found a paucity of TH expressing dopaminergic PGL neurons which arose in association with decreased Mash1 expression, the result of enhanced Hes 1 activity in $I d 2^{-/-}$neural precursors. These molecular changes correlate well with our observation of premature glial differentiation, since Hes1, a known inhibitor of neurogenesis (Ohtsuka et al., 2006), is permissive of astroglial differentiation (Cau et al., 2000).

Although it is possible that these findings reflect changes in early development, many lines of evidence support an unexpected role for $I d 2$ in adult neurogenesis. The most intriguing of these is the expression pattern of $I d 2$ in the murine adult brain. While expression of $I d 1$ and $I d 3$ is limited in the adult CNS, expression of $I d 2$ has been observed in adult neural progenitor cells, migrating neuroblasts, and postmitotic OB PGL interneurons, as well as in the caudate-putamen and substantia nigra (Kitajima et al., 2006). This contrasts with the expression pattern of the final mammalian Id family member, Id4, which is highly expressed in primitive SVZ cells, lower in differentiating neuroblasts, and not present in postmitotic neurons (Yokota, 2001; Yun et al., 2004; Kitajima et al., 2006). The expression of Id2 in adult neural progenitor cells as well as PGL interneurons places it in a small group of transcription factors that are expressed in both primitive neuronal progenitor cells and a subset of their postmitotic progeny. To date, such transcription factors include Er81 (Stenman et al., 2003), Sp8 (Waclaw et al., 2006), and Pax6 (Hack et al., 2005; Kohwi et al., 2005). Our observations demonstrate a novel and specific proneural function for Id 2 in the adult CNS. Here, $I d 2$ is required for the differentiation of a subtype of olfactory neurons and functions by inhibiting an inhibitor of differentiation, Hes1.

Hes 1 is highly expressed in neural stem cells and its expression is associated with the inhibition of proneural genes, while downregulation of Hes 1 is associated with increased expression of proneural genes and subsequent differentiation (Nakamura et al., 2000). Hes 1 represents an intriguing target for $I d 2$ in this paradigm due to the ability of Hes1 to positively regulate neural stem cell and neuroblast proliferation and inhibit neural differentiation, while allowing astrocyte differentiation to occur (Figs. 5, 6) (Cau et al., 2000; Morrison et al., 2000; Hatakeyama et al., 2004). Id 2 has been demonstrated in a number of laboratories to interact directly with Hes1 (Jögi et al., 2002; Bai et al., 2007). Coexpres- 
sion of Id2 with Hes1 in the RMS may be required for the expression of Mash1 which initiates dopaminergic differentiation in migrating neuroblasts (Saino-Saito et al., 2004). Our data support the hypothesis that $\mathrm{Id} 2$ is required to inhibit astrogliogenesis and promote the Mash 1 dependent dopaminergic phenotype by inhibition of Hes1 protein function.

Our studies indicate that while loss of Id 2 inhibition of Hes 1 expression in neural progenitor cells in vitro greatly decreases cell proliferation, loss of Id2 function in vivo does not effect the adult SVZ stem cell population (Bai et al., 2007). Rather, loss of Id2 function results in a decrease in the TH expressing dopaminergic subset of newborn neurons in the PGL of the OB. This proneural role for Id 2 appears to be highly specific, as loss of Id2 does not affect CR-positive GABAergic OB neurons. Alterations in Notch activation of Hes 1 may be a major factor in this specificity. Notch activation of Hes1 is currently among the best described repressors of neural differentiation [for review, see Iso et al. (2003), Fischer and Gessler (2007)]. Notch is active in SVZ type-B cells and neuroblasts in the RMS, although this signal is then reduced as cells enter the OB (Givogri et al., 2006). Therefore, it appears likely that while Notch activation of Hes 1 is required for maintaining RMS neuroblasts in the undifferentiated state (Hatakeyama et al., 2004; Bai et al., 2007), attenuation of Notch signaling, as manifested by decreased Hes1 activity, occurs in association with expression of the dopaminergic differentiation program in the RMS (Saino-Saito et al., 2004). In support of this model, our data demonstrate that Id 2 alters the activity of Hes 1 at the posttranslational level and is required for dopaminergic cell-fate.

Cellular alterations in the $\mathrm{OB}$ of $I d 2^{-/-}$mice share characteristics with the histology of the small eye mouse in which Pax6 is deleted $\left(\right.$ Pax6 $^{-/-}$) (Jiménez et al., 2000; Kohwi et al., 2005). Also, heterozygous mutations of PAX6 in humans contribute to CNS malformations which include olfactory dysfunction (Malandrini et al., 2001; Sisodiya et al., 2001). Histological analysis of heterozygous small eye adult mice $\left(\mathrm{Pax}^{+/-}\right)$reveals that these animals develop an OB, but are deficient in OB PGL dopaminergic neurons (Kohwi et al., 2005). It is possible that a prodopaminergic role for Pax6 during development is retained in the adult neurogenic compartment. Our data suggest that $I d 2$ is critical for TH-positive PGL neural differentiation in the adult. We hypothesize that these two transcription factors, Pax6 and Id2, may therefore be active within an as yet undefined prodopaminergic signaling program. We found that Id 2 functions in dopaminergic precursors to inhibit Hes1, an inhibitor of differentiation.

In the $I d 2^{-1-}$ OB we saw not only a decrease in the number of dopaminergic neurons (Fig. 2) but also increased numbers of astroglia (Fig. 5). Astrocytic differentiation is often thought of as a default program in such primitive cells as embryonic stem cell derived neural progenitors and adult neural stem cells (Doetsch, 2003; Nakayama et al., 2006). We provide evidence suggesting that astrogliosis in the $I d 2^{-/-}$mouse (Figs. 4,5 ) is the result of increased numbers of newborn astrocytes emanating from the RMS (Figs. 4, 5). Could Id 2 act as a direct inhibitor of an as yet unappreciated bHLH proglial cell-fate determinant? Hes1 is known to be permissive of the astroglial cell-fate, while inhibiting neuronal differentiation (Hatakeyama et al., 2004). Interestingly, expression of Hes1 RNA in OB neurons has a pattern strikingly similar to that of $I d 2$ as identified using in situ hybridization [Allen Brain Institute (www.brain-map.org) (Hu et al., 2008)]. Experiments to identify specific signaling programs regulated by Hes1/Id2 interactions should provide insight into the interface of astrocytic and dopaminergic differentiation.
Id $2^{-1-}$ mice do not discriminate different odorants as well as WT mice (Fig. 3) presumably as a result of the loss of dopaminergic neurons. Loss of $\mathrm{OB}$ dopaminergic neurons and anosmia are characteristics of several neurodegenerative diseases (Ansari and Johnson, 1975; Berendse et al., 2001; Moberg et al., 2006; Kranick and Duda, 2008). Parkinson's disease (PD) is associated with alterations in motor function occurring as the result of the degeneration of dopaminergic neurons of the nigrostriatal pathway (Nussbaum and Polymeropoulos, 1997), and PD patients are often anosmic. Interestingly, the expression of $I d 2$ is seen in adult nigrostriatal dopaminergic neurons (Kitajima et al., 2006). Alzheimer's disease is associated with altered olfactory capability and depletion of the dopamine transporter (DAT) and the D2 dopamine receptor (Joyce et al., 1997; Djordjevic et al., 2008). Schizophrenia is also associated with anosmia, and is linked to alterations in the function of dopamine receptors (Coon et al., 1993; Shah et al., 1995; Ilani et al., 2001). These observations and the work reported here suggest a role for $I d 2$ in mediating dopaminergic neural function beyond the $\mathrm{OB}$, and raise the possibility of other more subtle alterations within the brains of mice lacking $I d 2$. Currently our laboratory is investigating the potential that other populations of dopaminergic neurons, particularly within the basal ganglia, are affected by the loss of $I d 2$. A role for $I d 2$ in the generation of cerebral dopaminergic neurons would suggest that the $I d 2^{-{ }^{-}}$mouse may be a relevant model for future studies of neurodegenerative disease.

\section{References}

Andres-Barquin PJ, Hernandez MC, Israel MA (1999) Id4 expression induces apoptosis in astrocytic cultures and is down-regulated by activation of the cAMP-dependent signal transduction pathway. Exp Cell Res 247:347-355.

Ansari KA, Johnson A (1975) Olfactory function in patients with Parkinson's disease. J Chronic Dis 28:493-497.

Bai G, Sheng N, Xie Z, Bian W, Yokota Y, Benezra R, Kageyama R, Guillemot F, Jing N (2007) Id sustains Hes1 expression to inhibit precocious neurogenesis by releasing negative autoregulation of Hes1. Dev Cell 13:283-297.

Benezra R, Davis RL, Lockshon D, Turner DL, Weintraub H (1990) The protein Id: a negative regulator of helix-loop-helix DNA binding proteins. Cell 61:49-59.

Berendse HW, Booij J, Francot CM, Bergmans PL, Hijman R, Stoof JC, Wolters EC (2001) Subclinical dopaminergic dysfunction in asymptomatic Parkinson's disease patients' relatives with a decreased sense of smell. Ann Neurol 50:34-41.

Bertrand N, Castro DS, Guillemot F (2002) Proneural genes and the specification of neural cell types. Nat Rev Neurosci 3:517-530.

Bovetti S, Peretto P, Fasolo A, De Marchis S (2007) Spatio-temporal specification of olfactory bulb interneurons. J Mol Histol 38:563-569.

Cai L, Morrow EM, Cepko CL (2000) Misexpression of basic helix-loophelix genes in the murine cerebral cortex affects cell fate choices and neuronal survival. Development 127:3021-3030.

Cau E, Gradwohl G, Casarosa S, Kageyama R, Guillemot F (2000) Hes genes regulate sequential stages of neurogenesis in the olfactory epithelium. Development 127:2323-2332.

Chae JH, Stein GH, Lee JE (2004) NeuroD: the predicted and the surprising. Mol Cells 18:271-288.

Coon H, Byerley W, Holik J, Hoff M, Myles-Worsley M, Lannfelt L, Sokoloff P, Schwartz JC, Waldo M, Freedman R, et al (1993) Linkage analysis of schizophrenia with five dopamine receptor genes in nine pedigrees. Am J Hum Genet 52:327-334.

Dellovade TL, Pfaff DW, Schwanzel-Fukuda M (1998) Olfactory bulb development is altered in small-eye (Sey) mice. J Comp Neurol 402:402-418.

De Marchis S, Bovetti S, Carletti B, Hsieh YC, Garzotto D, Peretto P, Fasolo A, Puche AC, Rossi F (2007) Generation of distinct types of periglomerular olfactory bulb interneurons during development and in adult mice: implication for intrinsic properties of the subventricular zone progenitor population. J Neurosci 27:657-664. 
Djordjevic J, Jones-Gotman M, De Sousa K, Chertkow H (2008) Olfaction in patients with mild cognitive impairment and Alzheimer's disease. Neurobiol Aging 29:693-706.

Doetsch F (2003) The glial identity of neural stem cells. Nat Neurosci 6:1127-1134.

Doetsch F, García-Verdugo JM, Alvarez-Buylla A (1997) Cellular composition and three-dimensional organization of the subventricular germinal zone in the adult mammalian brain. J Neurosci 17:5046-5061.

Doetsch F, Caillé I, Lim DA, García-Verdugo JM, Alvarez-Buylla A (1999) Subventricular zone astrocytes are neural stem cells in the adult mammalian brain. Cell 97:703-716.

Fischer A, Gessler M (2007) Delta-Notch-and then? Protein interactions and proposed modes of repression by Hes and Hey bHLH factors. Nucleic Acids Res 35:4583-4596.

Florio M, Hernandez MC, Yang H, Shu HK, Cleveland JL, Israel MA (1998) Id 2 promotes apoptosis by a novel mechanism independent of dimerization to basic helix-loop-helix factors. Mol Cell Biol 18:5435-5444.

Galton VA, Wood ET, St Germain EA, Withrow CA, Aldrich G, St Germain GM, Clark AS, St Germain DL (2007) Thyroid hormone homeostasis and action in the type 2 deiodinase-deficient rodent brain during development. Endocrinology 148:3080-3088.

García-Verdugo JM, Doetsch F, Wichterle H, Lim DA, Alvarez-Buylla A (1998) Architecture and cell types of the adult subventricular zone: in search of the stem cells. J Neurobiol 36:234-248.

Gheusi G, Cremer H, McLean H, Chazal G, Vincent JD, Lledo PM (2000) Importance of newly generated neurons in the adult olfactory bulb for odor discrimination. Proc Natl Acad Sci U S A 97:1823-1828.

Givogri MI, de Planell M, Galbiati F, Superchi D, Gritti A, Vescovi A, de Vellis J, Bongarzone ER (2006) Notch signaling in astrocytes and neuroblasts of the adult subventricular zone in health and after cortical injury. Dev Neurosci 28:81-91.

Guillemot F (1999) Vertebrate bHLH genes and the determination of neuronal fates. Exp Cell Res 253:357-364.

Hack MA, Saghatelyan A, de Chevigny A, Pfeifer A, Ashery-Padan R, Lledo PM, Götz M (2005) Neuronal fate determinants of adult olfactory bulb neurogenesis. Nat Neurosci 8:865-872.

Harding JW, Getchell TV, Margolis FL (1978) Denervation of the primary olfactory pathway in mice. V. Long-term effect of intranasal $\mathrm{ZnSO} 4$ irrigation on behavior, biochemistry and morphology. Brain research 140:271-285.

Hatakeyama J, Bessho Y, Katoh K, Ookawara S, Fujioka M, Guillemot F, Kageyama R (2004) Hes genes regulate size, shape and histogenesis of the nervous system by control of the timing of neural stem cell differentiation. Development 131:5539-5550.

Hirata H, Yoshiura S, Ohtsuka T, Bessho Y, Harada T, Yoshikawa K, Kageyama R (2002) Oscillatory expression of the bHLH factor Hes1 regulated by a negative feedback loop. Science 298:840-843.

Hu W, Saba L, Kechris K, Bhave SV, Hoffman PL, Tabakoff B (2008) Genomic insights into acute alcohol tolerance. J Pharmacol Exp Ther 326:792-800.

Iavarone A, Garg P, Lasorella A, Hsu J, Israel MA (1994) The helix-loophelix protein Id-2 enhances cell proliferation and binds to the retinoblastoma protein. Genes Dev 8:1270-1284.

Ilani T, Ben-Shachar D, Strous RD, Mazor M, Sheinkman A, Kotler M, Fuchs S (2001) A peripheral marker for schizophrenia: Increased levels of D3 dopamine receptor mRNA in blood lymphocytes. Proc Natl Acad Sci U S A 98:625-628.

Iso T, Kedes L, Hamamori Y (2003) HES and HERP families: multiple effectors of the Notch signaling pathway. J Cell Physiol 194:237-255.

Jiménez D, Garcia C, de Castro F, Chédotal A, Sotelo C, de Carlos JA, Valverde F, López-Mascaraque L (2000) Evidence for intrinsic development of olfactory structures in Pax-6 mutant mice. J Comp Neurol 428:511-526.

Jögi A, Persson P, Grynfeld A, Påhlman S, Axelson H (2002) Modulation of basic helix-loop-helix transcription complex formation by Id proteins during neuronal differentiation. J Biol Chem 277:9118-9126.

Joyce JN, Smutzer G, Whitty CJ, Myers A, Bannon MJ (1997) Differential modification of dopamine transporter and tyrosine hydroxylase mRNAs in midbrain of subjects with Parkinson's, Alzheimer's with parkinsonism, and Alzheimer's disease. Mov Disord 12:885-897.

Kitajima K, Takahashi R, Yokota Y (2006) Localization of Id2 mRNA in the adult mouse brain. Brain Res 1073-1074:93-102.
Kohwi M, Osumi N, Rubenstein JL, Alvarez-Buylla A (2005) Pax6 is required for making specific subpopulations of granule and periglomerular neurons in the olfactory bulb. J Neurosci 25:6997-7003.

Kranick SM, Duda JE (2008) Olfactory dysfunction in Parkinson's disease. Neurosignals 16:35-40.

Lemasson M, Saghatelyan A, Olivo-Marin JC, Lledo PM (2005) Neonatal and adult neurogenesis provide two distinct populations of newborn neurons to the mouse olfactory bulb. J Neurosci 25:6816-6825.

Lim DA, Huang YC, Alvarez-Buylla A (2007) The adult neural stem cell niche: lessons for future neural cell replacement strategies. Neurosurg Clin N Am 18:81-92, ix.

Lois C, García-Verdugo JM, Alvarez-Buylla A (1996) Chain migration of neuronal precursors. Science 271:978-981.

Malandrini A, Mari F, Palmeri S, Gambelli S, Berti G, Bruttini M, Bardelli AM, Williamson K, van Heyningen V, Renieri A (2001) PAX6 mutation in a family with aniridia, congenital ptosis, and mental retardation. Clin Genet 60:151-154

Manglapus GL, Youngentob SL, Schwob JE (2004) Expression patterns of basic helix-loop-helix transcription factors define subsets of olfactory progenitor cells. J Comp Neurol 479:216-233.

Martoncíková M, Raceková E, Orendácová J (2006) The number of proliferating cells in the rostral migratory stream of rat during the first postnatal month. Cell Mol Neurobiol 26:1453-1461.

Merson TD, Dixon MP, Collin C, Rietze RL, Bartlett PF, Thomas T, Voss AK (2006) The transcriptional coactivator Querkopf controls adult neurogenesis. J Neurosci 26:11359-11370.

Moberg PJ, Arnold SE, Doty RL, Gur RE, Balderston CC, Roalf DR, Gur RC, Kohler CG, Kanes SJ, Siegel SJ, Turetsky BI (2006) Olfactory functioning in schizophrenia: relationship to clinical, neuropsychological, and volumetric MRI measures. J Clin Exp Neuropsychol 28:1444-1461.

Mori K, Shepherd GM (1994) Emerging principles of molecular signal processing by mitral/tufted cells in the olfactory bulb. Semin Cell Biol $5: 65-74$.

Mori S, Nishikawa SI, Yokota Y (2000) Lactation defect in mice lacking the helix-loop-helix inhibitor Id2. EMBO J 19:5772-5781.

Morrison SJ, Perez SE, Qiao Z, Verdi JM, Hicks C, Weinmaster G, Anderson DJ (2000) Transient Notch activation initiates an irreversible switch from neurogenesis to gliogenesis by neural crest stem cells. Cell 101:499-510.

Morshead CM, van der Kooy D (1992) Postmitotic death is the fate of constitutively proliferating cells in the subependymal layer of the adult mouse brain. J Neurosci 12:249-256.

Morshead CM, Craig CG, van der Kooy D (1998) In vivo clonal analyses reveal the properties of endogenous neural stem cell proliferation in the adult mammalian forebrain. Development 125:2251-2261.

Nakamura Y, Sakakibara S, Miyata T, Ogawa M, Shimazaki T, Weiss S, Kageyama R, Okano H (2000) The bHLH gene hesl as a repressor of the neuronal commitment of CNS stem cells. J Neurosci 20:283-293.

Nakayama T, Sai T, Otsu M, Momoki-Soga T, Inoue N (2006) Astrocytogenesis of embryonic stem-cell-derived neural stem cells: Default differentiation. Neuroreport 17:1519-1523.

Nussbaum RL, Polymeropoulos MH (1997) Genetics of Parkinson's disease. Hum Mol Genet 6:1687-1691.

Ohtsuka T, Imayoshi I, Shimojo H, Nishi E, Kageyama R, McConnell SK (2006) Visualization of embryonic neural stem cells using Hes promoters in transgenic mice. Mol Cell Neurosci 31:109-122.

Park CH, Kang JS, Kim JS, Chung S, Koh JY, Yoon EH, Jo AY, Chang MY, Koh HC, Hwang S, Suh-Kim H, Lee YS, Kim KS, Lee SH (2006) Differential actions of the proneural genes encoding Mash1 and neurogenins in Nurr1-induced dopamine neuron differentiation. J Cell Sci 119:2310-2320.

Parrish-Aungst S, Shipley MT, Erdelyi F, Szabo G, Puche AC (2007) Quantitative analysis of neuronal diversity in the mouse olfactory bulb. J Comp Neurol 501:825-836.

Petreanu L, Alvarez-Buylla A (2002) Maturation and death of adult-born olfactory bulb granule neurons: role of olfaction. J Neurosci 22:6106-6113.

Porteus MH, Bulfone A, Liu JK, Puelles L, Lo LC, Rubenstein JL (1994) DLX-2, MASH-1, and MAP-2 expression and bromodeoxyuridine incorporation define molecularly distinct cell populations in the embryonic mouse forebrain. J Neurosci 14:6370-6383.

Reynolds BA, Weiss S (1992) Generation of neurons and astrocytes from 
isolated cells of the adult mammalian central nervous system. Science 255:1707-1710.

Reynolds BA, Weiss S (1996) Clonal and population analyses demonstrate that an EGF-responsive mammalian embryonic CNS precursor is a stem cell. Dev Biol 175:1-13.

Saino-Saito S, Sasaki H, Volpe BT, Kobayashi K, Berlin R, Baker H (2004) Differentiation of the dopaminergic phenotype in the olfactory system of neonatal and adult mice. J Comp Neurol 479:389-398.

Shah M, Coon H, Holik J, Hoff M, Helmer V, Panos P, Byerley W (1995) Mutation scan of the D1 dopamine receptor gene in 22 cases of bipolar I disorder. Am J Med Genet 60:150-153.

Shepherd GM, Chen WR, Willhite D, Migliore M, Greer CA (2007) The olfactory granule cell: from classical enigma to central role in olfactory processing. Brain Res Rev 55:373-382.

Shepherd GMG (1998) The synaptic organization of the brain, Ed 4 (Shepherd GMG, ed). New York: Oxford UP.

Sisodiya SM, Free SL, Williamson KA, Mitchell TN, Willis C, Stevens JM, Kendall BE, Shorvon SD, Hanson IM, Moore AT, van Heyningen V (2001) PAX6 haploinsufficiency causes cerebral malformation and olfactory dysfunction in humans. Nat Genet 28:214-216.

Stenman J, Toresson H, Campbell K (2003) Identification of two distinct progenitor populations in the lateral ganglionic eminence: implications for striatal and olfactory bulb neurogenesis. J Neurosci 23:167-174.
Stoykova A, Gruss P (1994) Roles of Pax-genes in developing and adult brain as suggested by expression patterns. J Neurosci 14:1395-1412.

Takebayashi K, Sasai Y, Sakai Y, Watanabe T, Nakanishi S, Kageyama R (1994) Structure, chromosomal locus, and promoter analysis of the gene encoding the mouse helix-loop-helix factor HES-1. Negative autoregulation through the multiple $\mathrm{N}$ box elements. J Biol Chem 269:5150-5156.

Waclaw RR, Allen ZJ 2nd, Bell SM, Erdélyi F, Szabó G, Potter SS, Campbell K (2006) The zinc finger transcription factor Sp8 regulates the generation and diversity of olfactory bulb interneurons. Neuron 49:503-516.

Yang HK, Sundholm-Peters NL, Goings GE, Walker AS, Hyland K, Szele FG (2004) Distribution of doublecortin expressing cells near the lateral ventricles in the adult mouse brain. J Neurosci Res 76:282-295.

Yokota Y (2001) Id and development. Oncogene 20:8290-8298.

Yokota Y, Mansouri A, Mori S, Sugawara S, Adachi S, Nishikawa S, Gruss P (1999) Development of peripheral lymphoid organs and natural killer cells depends on the helix-loop-helix inhibitor Id2. Nature 397:702-706.

Yun K, Potter S, Rubenstein JL (2001) Gsh2 and Pax6 play complementary roles in dorsoventral patterning of the mammalian telencephalon. Development 128:193-205.

Yun K, Mantani A, Garel S, Rubenstein J, Israel MA (2004) Id4 regulates neural progenitor proliferation and differentiation in vivo. Development 131:5441-5448. 